\title{
The apical conjugate efflux pump ABCC2 (MRP2)
}

\author{
Anne T. Nies • Dietrich Keppler
}

Received: 17 May 2006 / Accepted: 29 May 2006 / Published online: 18 July 2006

(C) Springer-Verlag 2006

\begin{abstract}
ABCC} 2$ is a member of the multidrug resistance protein subfamily localized exclusively to the apical membrane domain of polarized cells, such as hepatocytes, renal proximal tubule epithelia, and intestinal epithelia. This localization supports the function of $\mathrm{ABCC} 2$ in the terminal excretion and detoxification of endogenous and xenobiotic organic anions, particularly in the unidirectional efflux of substances conjugated with glutathione, glucuronate, or sulfate, as exemplified by leukotriene $\mathrm{C}_{4}$, bilirubin glucuronosides, and some steroid sulfates. The hepatic $\mathrm{ABCC} 2$ pump contributes to the driving forces of bile flow. Acquired or hereditary deficiency of $\mathrm{ABCC} 2$, the latter known as Dubin-Johnson syndrome in humans, causes an increased concentration of bilirubin glucuronosides in blood because of their efflux from hepatocytes via the basolateral $\mathrm{ABCC} 3$, which compensates for the deficiency in $\mathrm{ABCC} 2$-mediated apical efflux. In this article we provide an overview on the molecular characteristics of $\mathrm{ABCC} 2$ and its expression in various tissues and species. We discuss the transcriptional and posttranscriptional regulation of $\mathrm{ABCC} 2$ and review approaches to the functional analysis providing information on its substrate specificity. A comprehensive list of sequence variants in the human $A B C C 2$ gene summarizes predicted and proven functional consequences, including variants leading to Dubin-Johnson syndrome.
\end{abstract}

\footnotetext{
A. T. Nies $(\bowtie) \cdot$ D. Keppler

Division of Tumor Biochemistry,

German Cancer Research Center,

Im Neuenheimer Feld 280,

D-69120 Heidelberg, Germany

e-mail: a.nies@dkfz.de

D. Keppler

email: d.keppler@dkfz.de
}

Keywords $\mathrm{ABCC} 2$ transporter.

Apical conjugate export pump - Detoxification by $\mathrm{ABCC} 2$.

Dubin-Johnson syndrome .

Membrane topology predicted for $\mathrm{ABCC} 2$.

Multidrug resistance protein 2 .

Sequence variants of $\mathrm{ABCC} 2$.

Substrate specificity of $\mathrm{ABCC} 2$

\section{Introduction}

The multidrug resistance protein $2(\mathrm{ABCC} 2)$ was the second member of the subfamily of MRP efflux pumps to be cloned from rat and human tissues [13, 60, 114, 133, 165]. The function of rat Abcc 2 was recognized long before its cloning by studies on the hepatobiliary elimination of organic anions in normal and transport-deficient mutant rats $[54,55,64,131,163]$. The loss of ATP-dependent transport across the hepatocyte canalicular membrane was identified in these mutant rats using inside-out membrane vesicles and various glutathione (GSH) $S$-conjugates as substrates, notably leukotriene $\mathrm{C}_{4}\left(\mathrm{LTC}_{4}\right)$ [57]. Thus, the difference between canalicular membrane vesicles from normal and transport-deficient mutant rats with respect to ATP-dependent transport of various anionic substrates has provided important insight into the substrate specificity of the conjugate export pump Abcc2. Moreover, the similar substrate spectrum of $\mathrm{Abcc} 2$ and $\mathrm{ABCC} 1$ [89] has supported the identification of substrates for $\mathrm{ABCC} 1$, which had been cloned by Cole et al. [21], 2 years before the identification of the first transport substrates of ABCC1 $[105,120]$. The link between the ATP-dependent transport of $\mathrm{LTC}_{4}$ and $\mathrm{ABCC} 1$ was made primarily by photoaffinity labeling using $\mathrm{LTC}_{4}$ as a photolabile high-affinity substrate which served to label mouse Abccl [106] and human 
ABCC1 ([66, 105]; reviewed by Jedlitschky and Keppler [65]). This photoaffinity labeling approach [33, 105, 106] had indicated a $190-\mathrm{kDa}$ integral membrane glycoprotein with properties similar to $\mathrm{ABCC} 1$ [106].

The localization of $\mathrm{ABCC} 2$ to the apical membrane of various polarized cells involved in the secretion of conjugated endogenous and xenobiotic substances favors the function of this efflux pump in the terminal phase of detoxification [83, 89]. Due to this substrate specificity, $\mathrm{ABCC} 2$, rather than $\mathrm{ABCB} 1$ or $\mathrm{ABCG} 2$, is the optimal pump for the elimination of conjugates of various toxins and carcinogens with GSH, glucuronate, or sulfate from hepatocytes into bile, or from kidney proximal tubules into urine, or from intestinal epithelial cells into the intestinal lumen. Particularly in nonpolarized cell types, additional members of the $\mathrm{ABCC}$ subfamily, such as $\mathrm{ABCC} 1$, may have this function in terminal detoxification.

$\mathrm{ABCC} 2$ plays a decisive role in the elimination of bilirubin glucuronosides from hepatocytes into bile. Accordingly, the absence of functional $\mathrm{ABCC} 2$ from the canalicular membrane $[72,82]$ causes conjugated hyperbilirubinemia, as observed in the hereditary disorder described by Dubin and Johnson [31]. Today, many sequence variants in the $A B C C 2$ gene have been identified, as described below, but only some of them cause DubinJohnson syndrome. The hereditary deficiency of ABCC 2 in humans, or of Abcc2 in the mutant rats mentioned above, and the recently generated Abcc2 knock-out mouse strains $[18,121,177]$ illustrate the key function of this apical efflux pump in the elimination of anionic conjugates from the body. It should be noted, however, that this loss of $\mathrm{ABCC} 2$ function is usually well tolerated and compensated by the upregulation of other membrane transporters, particularly of $\mathrm{ABCC} 3$ in the basolateral membrane of hepatocytes $[30,82,91]$.

\section{Functional characterization and substrate specificity of $\mathrm{ABCC2}$}

Insight into the substrate specificity of human or rodent $\mathrm{ABCC} 2 / \mathrm{Abcc} 2$ may be obtained on several experimental levels. A relatively simple indication whether a compound is transported by rat Abcc 2 is given by the comparative elimination of a compound into the bile of normal and Abcc2-deficient mutant rats [55, 64, 131]; however, intracellular metabolism and the presence of alternative efflux pumps in the canalicular membrane may obscure the results. Kinetic constants for rat Abcc 2 may be obtained by comparative studies with inside-out hepatocyte canalicular membrane vesicles isolated from normal and Abcc2deficient liver [57, 126, 127, 187], as detailed in Table 1. Clearly, the most informative data can be obtained with
Table 1 Substrate specificity of human and rat $\mathrm{ABCC} 2$

\begin{tabular}{ll}
\hline Substrate & $\begin{array}{l}K_{\mathrm{m}} \text { value } \\
(\mu \mathrm{M})\end{array}$ \\
\end{tabular}

Human ABCC2 (recombinant in vesicles)

Bilirubin

Monoglucuronosyl 0.7

Bisglucuronosyl 0.9

Leukotriene $\mathrm{C}_{4}$

$S$-Glutathionyl 2,4-dinitrobenzene

$17 \beta$-Glucuronosyl estradiol

Cholecystokinin peptide (CCK-8)

Monoglutathionyl chlorambucil

Bromosulfophthalein

Ethinylestradiol-3-O-glucuronide

p-Aminohippurate

$0.7 \quad[71]$

0.9 [71]

1 [24]

$6.5 \quad[32]$

$7.2 \quad[24]$

$8.1 \quad[109]$

$10 \quad[156]$

$12 \quad[25]$

$35 \quad[20]$

$880 \quad[107]$

$2,100 \quad[155]$

[53]

Methotrexate

[32]

$S$-Glutathionyl ethacrynic acid

[107]

Ochratoxin A

Estrone 3-sulfate

[95]

Rat Abcc2 (recombinant in vesicles)

$S$-Glutathionyl 2,4-dinitrobenzene

0.2

[61]

Bilirubin

Bisglucuronosyl

Monoglucuronosyl

0.5

[71]

Leukotriene $\mathrm{C}_{4}$

0.8

[71]

Sulfatolithocholyl taurine

$17 \beta$-Glucuronosyl estradiol

$\begin{array}{ll}1.1 & {[24]} \\ 3.9 & {[1]}\end{array}$

$6.9 \quad[24]$

5-(and 6)-Carboxy-2', 7'-

[24]

dichlorofluorescein

$p$-Aminohippurate

140

[185]

[173]

Rat Abcc2 (normal vs mutant in canalicular membrane vesicles)

Leukotriene $\mathrm{C}_{4}$

Leukotriene $\mathrm{D}_{4}$

Sulfatolithocholyl taurine

Fluo-3

$N$-Acetyl leukotriene $\mathrm{E}_{4}$

Glucuronosyl E3040

Glucuronosyl grepafloxacin

Sulfatochenodeoxycholyl taurine

Bromosulfophthalein

Temocaprilat

Pravastatin

Methotrexate

0.3

1.5

[57]

[57]

$1.5 \quad[1]$

$3.7 \quad[122]$

$5.2 \quad[57]$

5.7

[57]

[148]

7.2

[1]

8.8

[128]

31

93

220

[58]

Leukotriene $\mathrm{E}_{4}$

[187]

[113]

[57]

[57]

$S$-Glutathionyl 2,4-dinitrobenzene

[57]

$S$-Glutathionyl

Glutathione disulfide

Bilirubin

Monoglucuronosyl

[67]

Bisglucuronosyl

Glucuronosyl nafenopin

$[67,127]$

Glucuronosyl SN38 carboxylate

[66]

[19]

Glucuronosyl SN38 lactone

[19]

SN38 carboxylate

[19]

Thromboxane A2 receptor

[77]

antagonist (Z-335) 
inside-out membrane vesicles containing recombinant ABCC2 from human or other species expressed in cell lines such as human embryonic kidney cell line 293 [24], Madin-Darby canine kidney cell line (MDCKII) [24, 32], or Sf9 insect cells [171]. $K_{\mathrm{m}}$ values given for various substrates have been obtained with these inside-out membrane vesicles as summarized in Table 1 . ABCC2 purified to homogeneity has also been analyzed with respect to the ATP-dependent transport of $\mathrm{LTC}_{4}$ and ATPase activity [43, 44]. The ATPase activity of ABCC2 has been studied in detail in membrane vesicles [4]. Although this assay may provide valuable information, it cannot substitute for transport measurements using inside-out membrane vesicles, which allow for the determination of $K_{\mathrm{m}}$ values and for kinetic constants of inhibitors of transport across membranes.

More recently, double- and multiple-transfected polarized cells have been developed, which stably express an uptake transporter of the organic anion transporting polypeptide family in the basolateral membrane and ABCC2 in the apical membrane [25, 81, 95, 149]
(Fig. 1). With this in vitro system, functional analyses and identification of substrates for $\mathrm{ABCC} 2$ have become possible in a medium- to high-throughput format. However, $K_{\mathrm{m}}$ values cannot be obtained by the use of such doubletransfected cell lines.

The substrate specificity of $\mathrm{ABCC} 2$ is broad and comprises many organic anions, with the highest affinity for glucuronate and GSH conjugates of lipophilic substances, as exemplified by $\mathrm{LTC}_{4}$, which is an arachidonate derivative and a GSH conjugate (Table 1, reviewed by Jedlitschky and Keppler [65] and König et al. [91]). In addition, many anionic substances without anionic conjugate residues have been identified as substrates, such as methotrexate and bromosulfophthalein (Table 1). Reduced and oxidized GSH are additional substrates. Interestingly, Abcc2-deficient mutant rats cannot excrete GSH into their bile [131, 135]. It remains controversial whether this is due to low affinity transport of GSH by Abcc2 or due to the coefflux of GSH with additional compounds in a process well established for $\mathrm{ABCC} 1[110]$ and for ABCC4 [140, 141]. The differences in the substrate specificity between $\mathrm{ABCC} 2$ and $\mathrm{ABCC} 1$ are
Fig. 1 Immunolocalization of human $\mathrm{ABCC} 2$ (green) in different human tissues and in polarized epithelial MDCK cells double-transfected with the cDNAs encoding $\mathrm{ABCC} 2$ and the uptake transporter organic anion transporting polypeptide 1B1 (OATP1B1). Pictures were taken with a confocal laser scanning microscope. The panel with the double transfectants shows the normal xy-view and an optical xz-section taken along the dashed line as indicated in the xy-view. ABCC2 is localized in the apical membrane of hepatocytes in liver, of enterocytes in duodenum, and of proximal tubule epithelial cells in kidney. The uptake of organic anions from blood into hepatocytes is mediated by the basolaterally localized OATP1B1, in addition to other organic anion transporters. Double-transfected $[25,81,108,109,149,157]$ or quadruple-transfected [95] polarized cells coexpressing organic anion transporters in their basolateral and the conjugate efflux pump $\mathrm{ABCC} 2$ in their apical membrane serve as a valuable system to study the vectorial transport of substances that undergo hepatobiliary elimination in humans. Bars, $10 \mu \mathrm{m}$
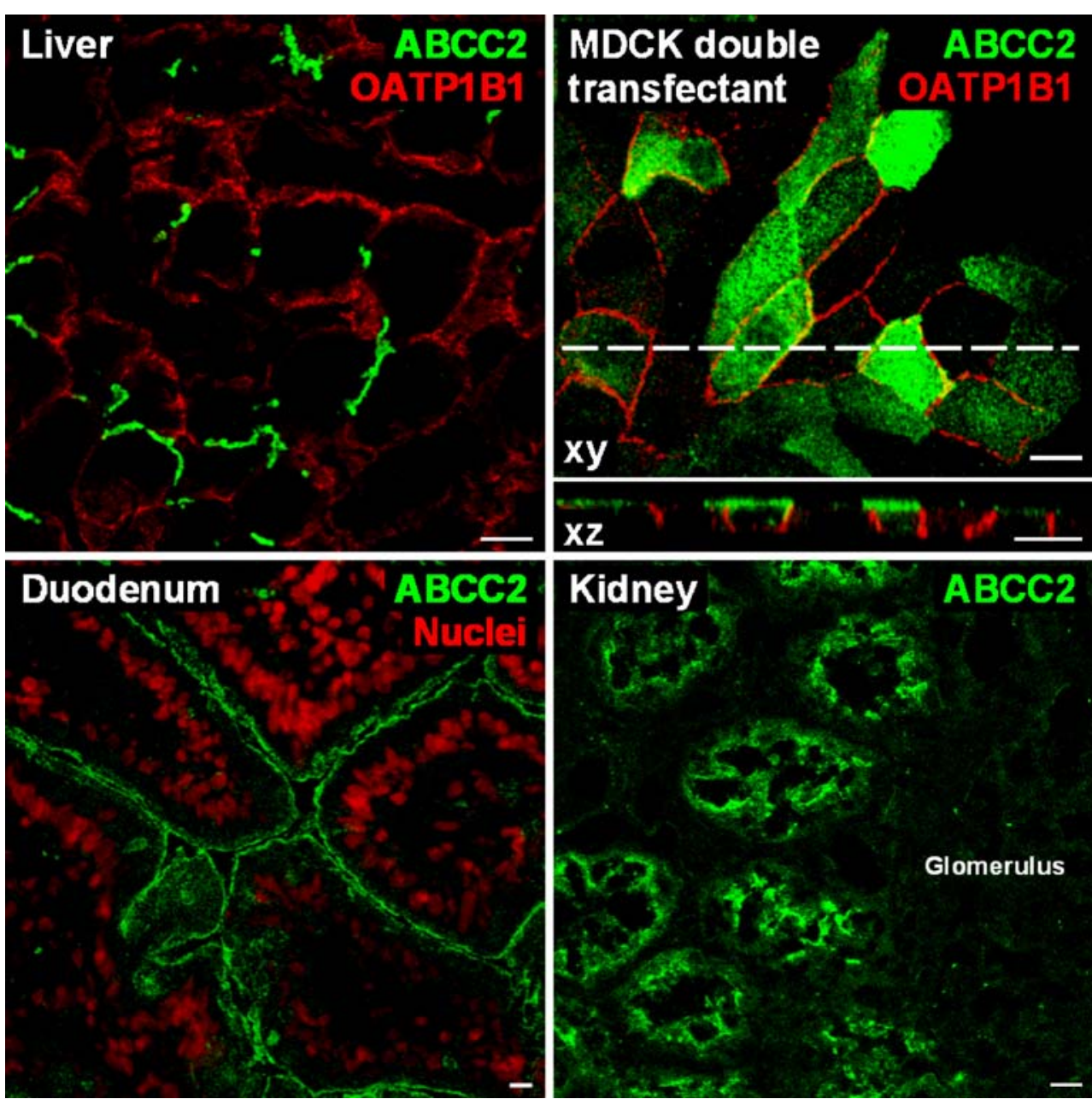
limited and often detectable only by the determination of kinetic constants $[65,89]$.

\section{Molecular characterization of $\mathrm{ABCC} 2$}

Abcc2 cDNA was initially identified and cloned as a fragment from rat liver, using degenerate oligonucleotides complementary to human $A B C C 1$ [21] and Leishmania $\operatorname{ltpgp} A$ [114]. This $A b c c 2$ cDNA fragment was amplified from normal rat liver, but not from the liver of mutant rats that were deficient in the hepatobiliary excretion of anionic conjugates [114]. The subsequent cloning and analysis of the full-length rat $A b c c 2$ cDNA identified Abcc2 [Mrp2; formerly described as cMrp and canalicular multispecific organic anion transporter (cMoat)] as an ABCC1-related protein localized in the canalicular membrane of hepatocytes [13, 133] (Fig. 1). At present, the full-length sequences from six mammalian species, including the orthologs from human, rhesus monkey, rat, rabbit, mouse, $\operatorname{dog}[13,22,37,133,165,172]$, and from three other vertebrates, are known (Table 2). ABCC2-related sequences are also present in many other organisms, including Caenorhabditis elegans [11] and Arabidopsis thaliana [139]. Within the human ABCC subfamily, ABCC2 has the highest degree of amino acid sequence identity with ABCC1 (50\%) and the lowest with ABCC11 and cystic fibrosis transmembrane conductance regulator (Table 2). ABCC2 is structurally and functionally very distinct from MDR1 P-glycoprotein (ABCB1), which belongs to a different subfamily of $\mathrm{ABC}$ transporters with which ABCC2 shares only about $26 \%$ amino acid sequence identity. The human $A B C C 2$ gene is located on chromosome 10q24 [165], spans about 65 kilobase pairs, and consists of 32 exons with a high proportion of class 0 introns [168, 170].

The predicted topology of the subfamily of ABCC/MRP efflux pumps is related to most of the other human $\mathrm{ABC}$ transporters and comprises two polytopic membrane-spanning domains, each followed by a nucleotide-binding domain $[45,96]$. However, ABCC2, together with ABCC1, $\mathrm{ABCC} 3, \mathrm{ABCC} 6$, and $\mathrm{ABCC} 10$, is unique in having an additional amino-terminal polytopic membrane-spanning domain (Fig. 2) that may be required for proper function

Table 2 Amino acid sequence identity of human ABCC2 with the other members of the human ABCC subfamily and with Abcc2 orthologs from other species

\begin{tabular}{|c|c|c|c|c|c|c|c|}
\hline Species & Symbol & $\begin{array}{l}\text { Alternate } \\
\text { name }\end{array}$ & $\begin{array}{l}\text { Chromosomal } \\
\text { localization }\end{array}$ & $\begin{array}{l}\text { Number of } \\
\text { exons }^{\text {a }}\end{array}$ & $\begin{array}{l}\text { Number of } \\
\text { amino acids }\end{array}$ & $\begin{array}{l}\text { Identity } \\
(\%)^{\mathrm{b}}\end{array}$ & $\begin{array}{l}\text { Accession } \\
\text { number }^{\mathrm{c}}\end{array}$ \\
\hline \multicolumn{8}{|c|}{ The human ABCC subfamily } \\
\hline \multirow[t]{13}{*}{ Human } & $\mathrm{ABCC} 2$ & MRP2 & $10 q 24$ & 32 & 1,545 & 100 & NP_000383 \\
\hline & $\mathrm{ABCC} 1$ & MRP1 & $16 \mathrm{p} 13.1$ & 31 & 1,531 & 50 & NP_004987 \\
\hline & $\mathrm{ABCC} 3$ & MRP3 & $17 \mathrm{q} 22$ & 31 & 1,527 & 48 & NP_003777 \\
\hline & $\mathrm{ABCC} 4$ & MRP4 & $13 q 32$ & 31 & 1,325 & 39 & NP_005836 \\
\hline & $\mathrm{ABCC} 5$ & MRP5 & $3 q 27$ & $32^{\S}$ & 1,437 & 38 & NP_005679 \\
\hline & ABCC6 & MRP6 & $16 \mathrm{p} 13.1$ & 31 & 1,503 & 40 & NP_001162 \\
\hline & CFTR & $\mathrm{ABCC} 7$ & $7 \mathrm{q} 31.2$ & 27 & 1,480 & 30 & NP_000483 \\
\hline & ABCC8 & SUR1 & $11 \mathrm{p} 15.1$ & $41^{\S}$ & 1,581 & 34 & NP_000343 \\
\hline & ABCC9 & SUR2A & $12 \mathrm{p} 12.1$ & $39^{\S}$ & 1,549 & 35 & NP_005682 \\
\hline & & SUR2B & $12 \mathrm{p} 12.1$ & $39^{\S}$ & 1,549 & 35 & NP_064693 \\
\hline & $\mathrm{ABCC} 10$ & MRP7 & $6 \mathrm{p} 21.1$ & 22 & 1,464 & 34 & NP_258261 \\
\hline & $\mathrm{ABCC} 11$ & MRP8 & $16 \mathrm{q} 12.1$ & 28 & 1,382 & 33 & NP_149163 \\
\hline & $\mathrm{ABCC} 12$ & MRP9 & $16 \mathrm{q} 12.1$ & 29 & 1,359 & 35 & NP_-150229 \\
\hline \multicolumn{8}{|c|}{ Human ABCC2 and other Abcc2 orthologs } \\
\hline Human & $\mathrm{ABCC} 2$ & & $10 \mathrm{q} 24$ & 32 & 1,545 & 100 & NP_000383 \\
\hline Rhesus monkey & Abcc2 & & & & 1,545 & 96 & AAY41167 \\
\hline Dog & Abcc2 & & 28 & $33^{\S}$ & 1,544 & 84 & AAS91646 \\
\hline Rabbit & Abcc2 & & & & 1,564 & 82 & CAA89004 \\
\hline Mouse & Abcc2 & & 19 & $32^{\S}$ & 1,543 & 78 & AAL36985 \\
\hline Rat & Abcc2 & & $1 q 51$ & & 1,541 & 78 & NP_036965 \\
\hline Chicken & Abcc2 & & 6 & $31^{\S}$ & 1,542 & 64 & XP_421698 \\
\hline Zebrafish & Abcc2 & & 13 & $26^{\S}$ & 1,567 & 59 & NP_956883 \\
\hline Little skate & Abcc2 & & & & 1,564 & 57 & AAL 92112 \\
\hline
\end{tabular}

${ }^{a}$ Compiled from Haimeur et al. [45] and König et al. [91] and "Gene" database at http://www.ncbi.nlm.nih.gov/entrez (symbol §)

${ }^{\mathrm{b}}$ Analyzed by the GAP tool of the Heidelberg Unix Sequence Analysis Resources program package at http://genome.dkfz-heidelberg.de

${ }^{\text {c} P r o t e i n ~ a c c e s s i o n ~ n u m b e r ~ f r o m ~ " P r o t e i n " ~ d a t a b a s e ~ a t ~ h t t p: / / w w w . n c b i . n l m . n i h . g o v / e n t r e z ~}$ 
and localization $[34,39,183]$. The extracellular location of the amino terminus was first predicted for rat Abcc2 by computational analysis [13] and subsequently proven experimentally [24]. Different algorithms, which have been used to calculate the probability of an amino acid sequence to be a transmembrane-spanning helix in a polytopic membrane protein, predicted only four transmembranespanning helices between the first and second nucleotidebinding domain of ABCC2 [91] (Fig. 2). This is in contrast to the established six transmembrane-spanning helices in the corresponding part of $\mathrm{ABCC} 1$ [21].

\section{Localization of $\mathrm{ABCC} 2$ in polarized cells and tissues}

The $\mathrm{ABCC} 2$ protein was, for the first time, localized in the apical (canalicular) membrane of rat [13] and human [82, 134] hepatocytes and, therefore, initially termed canalicular MRP (cMRP) [13] or cMOAT [133, 134, 165]. The subsequent identification of Abcc2 in the apical membrane of proximal tubule epithelial cells of rat kidney was the first demonstration of an extrahepatic localization of this conjugate efflux pump [150]. Besides human kidney [151], other polarized human tissues with $\mathrm{ABCC} 2$ being present in the apical membrane of the polarized cells include the small intestine [38, 147], colon [91], gallbladder [144], bronchi [91, 147], and placenta [159] (Fig. 1). Many of these polarized cell types express additional ABCC/MRP efflux pumps that are basolaterally localized, as exemplified in human hepatocytes where $\mathrm{ABCC} 3[90,94], \mathrm{ABCC} 4$ [140], and ABCC6 [6,91] were identified in the sinusoidal membrane. In contrast to these polarized tissues, the
$\mathrm{ABCC} 2$ protein is apparently not present in the human blood-testis barrier $[5,147]$ and in the blood-brain barrier in the human cortex $[125,147,188]$. However, ABCC2 was identified in brain capillaries of hippocampus specimens from patients with temporal lobe epilepsy [2] and in the rat blood-brain barrier after pilocarpine-induced epileptic seizures [52]. Moreover, some studies described Abcc2 in brain capillaries of normal rats $[115,176]$. Various human tissues do not express the $\mathrm{ABCC} 2$ protein in detectable amounts, such as the skin, exocrine pancreas, female reproductive system, lymphatic system, cardiovascular system, and connective tissue [147].

In addition to normal human tissues, the $\mathrm{ABCC} 2$ protein is also present in a number of human malignant tumors, as evidenced by immunostaining of clinical specimens from renal clear-cell [147, 151], hepatocellular [123, 190], ovarian [3, 147], and colorectal carcinomas [49, 147]. Using tissue microarrays, $\mathrm{ABCC} 2$ was detected in lung, breast, and gastric carcinomas [147]. In contrast, ABCC2 protein expression was negligible or absent in primary testicular tumors [5], pancreatic adenocarcinomas [92], and gliomas [12]. Because of its ability to confer resistance to a wide variety of anticancer drugs [17, 24, 53, 78], ABCC2 may be of clinical relevance by contributing to the multidrug resistance phenotype of several solid malignant human tumors.

Several cell lines endogenously expressing $\mathrm{ABCC} 2$ have been used to study ABCC2 function in intact cells. Some rat and human hepatoma cells acquire a hepatocyte-like polarity after several days in culture and form apical vacuoles or bile canaliculus-like structures between adjacent cells [14, 122]. Secretion of fluorescent ABCC2
Fig. 2 Predicted membrane topology of human $\mathrm{ABCC} 2$. Amino acids within the nucleotide-binding domains constituting the Walker A and B motifs and the family signature are in black. Tree-like structures indicate the location of putative $N$-glycosylation sites. This topology prediction with four transmembrane segments between the first and second nucleotide-binding domain is based on different algorithms, including TMpred (http:// www.ch.embnet.org/software/ TMPRED_form.html) and TopPred2 (http://bioweb.pasteur. $\mathrm{fr} /$ seqanal/interfaces/toppred. html). Sequence variants causing Dubin-Johnson syndrome are shown as detailed in Table 3. $M S D$, membrane-spanning domain

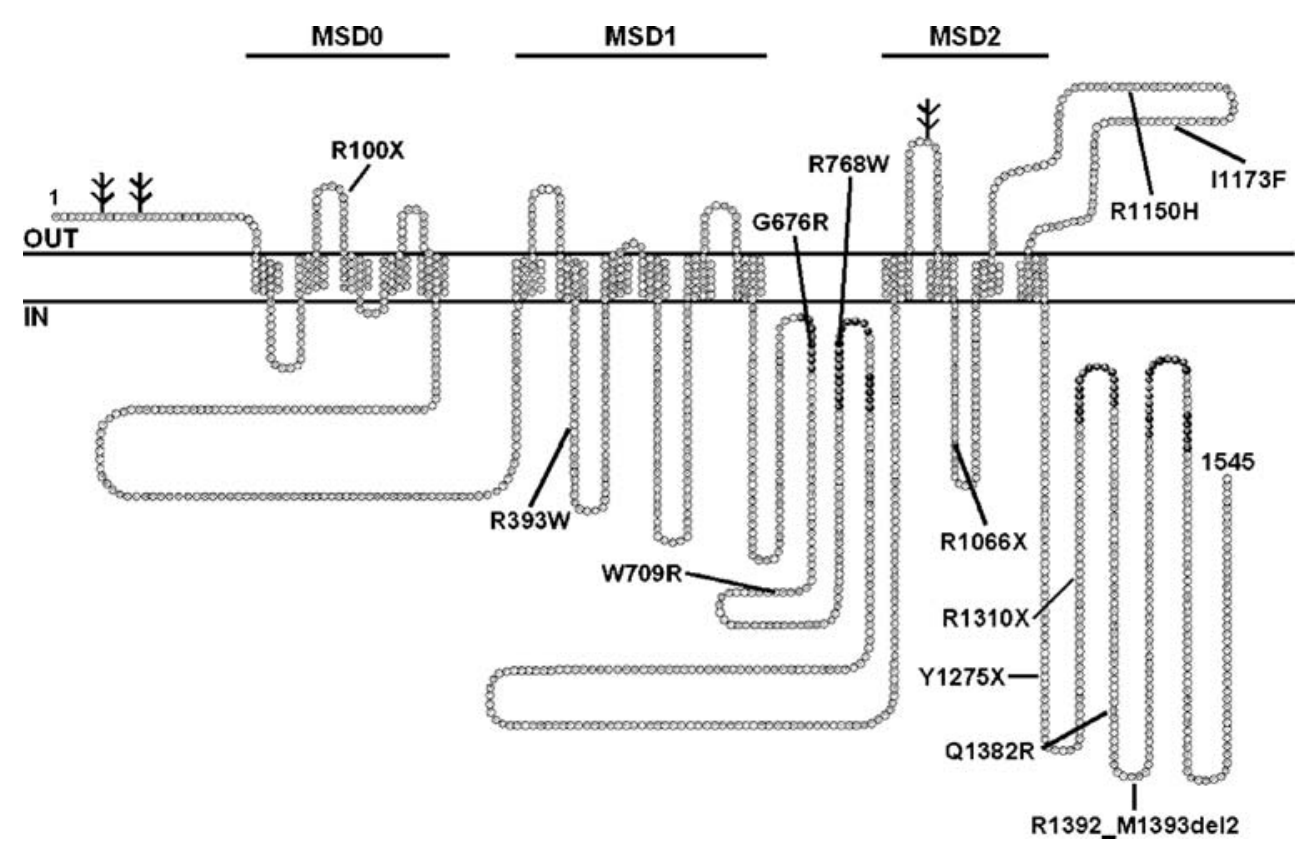


substrates into these apical vacuoles can be followed by live cell video microscopy $[14,91,122]$. Caco-2 cells, which are derived from a human colon carcinoma and also endogenously express $\mathrm{ABCC} 2$, gain an epithelial polarity with $\mathrm{ABCC} 2$ being present in the apical membrane when grown on certain filter membranes $[9,182]$. Polarized MDCK (or rather MDCKII) cells expressing recombinant human $\mathrm{ABCC} 2$ in their apical membrane are better defined as cell systems than Caco-2 cells to study the ABCC2mediated efflux of substances from cells [24, 32]. A major advancement came with the development of MDCK cells coexpressing one [25, 149] or more [95] human organic anion uptake transporters, localized in the basolateral membrane, together with the human apical efflux pump ABCC2 (Fig. 1). These double or quadruple transfectants are useful to study the vectorial transport of substances that undergo hepatobiliary elimination in humans without the need for studies with inside-out membrane vesicles containing the ABCC2 protein $[25,81,95,108,109,149$, 157].

$\mathrm{ABCC} 2$ is exclusively localized in the apical membrane of polarized cells. A cell type-dependent localization, as detected for $\mathrm{ABCC} 4$, which is present in the basolateral membrane of human hepatocytes [140] and in the apical membrane of kidney proximal tubule epithelial cells [174], has not been observed for $\mathrm{ABCC} 2$. Under certain experimental conditions, $\mathrm{ABCC} 2$ may be redistributed to the basolateral membrane, e.g., in rat hepatocyte couplets shortly after their isolation [142] and in human HepG2 cells after protein kinase $\mathrm{C}$ activation [100].

The molecular mechanisms by which $\mathrm{ABCC} 2$ is targeted to the apical membrane are incompletely understood. Some proteins have been reported to interact with $\mathrm{ABCC} 2$ in vitro. Radixin, a member of the ezrin/radixin/moesin family cross-linking actin with several integral membrane proteins [10], is apparently required for the proper apical localization of Abcc2 because radixin knock-out mice exhibit conjugated hyperbilirubinemia and a selective loss of the Abcc2 protein from the hepatocyte canalicular membrane [84]. Canalicular localization of human ABCC2 may similarly be dependent on radixin interaction [88]. Other proteins interacting with $\mathrm{ABCC} 2$ in vitro belong to the PSD95/Dlg/ZO-1 (PDZ) family and bind to C termini with the conserved sequence $T / S-X-\Phi$, with $X$ being any amino acid and $\Phi$ a hydrophobic amino acid. Interaction of ABCC2 with PDZK1 and other PDZ proteins has been described [48, 86] and most of the known ABCC2 orthologs (Table 2) have a consensus PDZ-binding motif at their $\mathrm{C}$ termini. Interestingly, PDZK1 knock-out mice have a proper apical localization of Abcc2 in kidney proximal tubule epithelial cells, indicating that the interaction of Abcc2 with PDZK1 is either not required in vivo or that other PDZ proteins are able to compensate [87].
Whereas one report proposed that the PDZ-binding motif is the apical targeting signal of $\mathrm{ABCC} 2$ [46], this was not confirmed by all other studies [34, 93, 124, 183]. These latter studies indicate that the apical targeting motif of $\mathrm{ABCC} 2$ is not a distinct, narrowly defined amino acid sequence, but rather appears to be composed of several motifs within different parts of $\mathrm{ABCC} 2$ that come together only in the intact protein.

\section{Transcriptional and posttranscriptional regulation of $\mathrm{ABCC} 2$}

$\mathrm{ABCC} 2$ is not only constitutively expressed, but its expression is also regulated on the transcriptional and posttranscriptional level in response to many endogenous and xenobiotic substances and to different disease states. Transcriptional regulation may result from changes in the intracellular concentrations of bile acids and of a number of lipophilic compounds that are ligands for nuclear hormone receptors. Additional posttranscriptional mechanisms may allow for a short-term regulation of $\mathrm{ABCC} 2 \mathrm{ABCC} 2$ regulation is often accompanied by a coordinate regulation of other bile salt transporters and of conjugating enzymes. These processes are described in detail by Gerk and Vore [40], Kullak-Ublick et al. [102], and van de Water et al. [175].

Cloning and characterization of the rat $A b c c 2$ and the human $A B C C 2$ promoters identified several consensus binding sites for both liver-specific and ubiquitous transcription factors [74, 160, 164]. The region between nucleotides -517 and -197 in front of the translation initiation codon is important for human $A B C C 2$ expression [160], with the transcriptional start-site being at nucleotide -247 . In addition, a hormone response element in the rat $A b c c 2$ promoter (ER-8) was identified, which is bound by heterodimers of the retinoid X receptor $\alpha(\mathrm{RXR} \alpha, \mathrm{NR} 2 \mathrm{~B} 1$ [129]) with the ligand-activated transcription factors farnesoid $\mathrm{X}$ receptor (FXR, NR1H4), pregnane $\mathrm{X}$ receptor (PXR, NR1I2), or constitutive androstane receptor (CAR, NR1I3) [73]. These nuclear receptors are, for example, activated by bile acids via FXR [132] by various xenobiotics such as the antibiotic rifampicin, the synthetic glucocorticoid dexamethasone, and pregnenolone $16 \alpha$-carbonitrile via PXR [8, 41, 85], or by phenobarbital via CAR [161]. Knowledge of the presence of the hormone response element ER-8 in the rat $A b c c 2$ promoter [73] may now explain studies which describe the induction of $A b c c 2$ mRNA and Abcc2 protein in primary cultures of rat hepatocytes by a number of xenobiotics, including the carcinogen 2-acetylaminofluorene, the anticancer drug cisplatin, the antifungal agent clotrimazole, the antibiotic cycloheximide, dexamethasone, the chemopreventive agents oltipraz and sulforaphane, phenobarbital, and pregnenolone $16 \alpha$-carbonitrile $[23,73,75,98$, 
137]. Additional factors are probably involved in ABCC2/ $A b c c 2$ regulation in vivo because phenobarbital or oltipraz treatment of rats did not increase $A b c c 2$ mRNA expression [23, 40, 42, 68]. In contrast, the feeding of mice with several compounds, e.g., the bile acids ursodeoxycholic acid and cholic acid [36], or the herbicide 2,4,5-trichlorophenoxyacetic acid [184], induced $A b c c 2$ mRNA and Abcc 2 protein expression, which may prevent the accumulation of potentially toxic bile acid conjugates or xenobiotics. Similarly, ABCC2 induction was detected in the liver of nonhuman primates [76] and in the intestines of humans [38] after treatment with the PXR ligand rifampicin.

ABCC2/Abcc2 regulation in disease states can also, at least in part, result from mediation via transcription factors. Down-regulation of $A b c c 2 \mathrm{mRNA}$ and Abcc 2 protein in rat liver after experimental cholestasis induced either by bile duct ligation or endotoxin treatment $[99,169,178]$ may be explained by an upregulation of the inflammatory cytokine interleukin- $1 \beta$, which in turn down-regulates the heterodimeric retinoic acid receptor $\alpha / \operatorname{RXR} \alpha$, leading to downregulation of $A b c c 2$ promoter activity [27]. Interestingly, Abcc 2 expression in the kidney is preserved or up-regulated during cholestasis [27, 103]. In humans, $A B C C 2$ mRNA levels were reduced in livers from patients with primary sclerosing cholangitis [130] or with obstructive cholestasis [153]. Obstructive cholestasis leads to reduced ABCC2 protein levels in the intestine without an effect on $A B C C 2$ mRNA expression [28].

Besides this transcriptional regulation, several studies describe the posttranscriptional regulation of $\mathrm{ABCC} 2 /$ Abcc2. One mechanism is the modulation of the amount of the conjugate efflux pump in the apical membrane by recruitment of transporter molecules from intracellular pools or their retrieval into these pools. Insertion of Abcc2 into the canalicular membrane of rat hepatocytes may depend on the lipid kinase phosphoinositide 3-kinase [116], on protein kinase C [7], or on cyclic AMP [142]. Retrieval of rat Abcc2 transporter molecules from the canalicular membrane into the hepatocyte has been detected under different cholestatic conditions [119, 136, 169], after phalloidin treatment [143], after cytokine stimulation [29, 99], and under hyperosmolar conditions [29, 97]. Under these conditions, immunostaining of Abcc2 is no longer confined to the canalicular membrane, but appears "fuzzy," which is interpreted as an accumulation of transporter molecules within the hepatocyte. A comparable fuzzy immunostaining, indicative of endocytic retrieval of transporter molecules, has been described in human liver diseases, e.g., inflammation-induced icteric cholestasis [189], obstructive cholestasis [153, 186], and advanced stages of primary biliary cirrhosis $[88,101]$.

The amount of transporter molecules in the hepatocyte canalicular membrane can also be regulated by a change in their synthesis or degradation rate. The physiological halflife of rat Abcc 2 in the hepatocyte canalicular membrane is about $27 \mathrm{~h}$ [69]. In normal rat liver, the synthesis and degradation rates result in Abcc 2 protein levels that appear to be similar within a lobule [136]. During cholestasis, however, Abcc2 in the periportal hepatocytes is more rapidly degraded than under normal conditions, leading to the observation that Abcc 2 is concentrated near the central (perivenous) area of the liver lobule [136]. Decreased Abcc2 protein levels, but unaltered Abcc 2 mRNA levels, were also detected in rats treated with ethinylestradiol [169] and in pregnant rats in comparison with control rats [15]. Clofibrate, which is a ligand for the peroxisome proliferator-activated receptor $\alpha(\operatorname{PPAR} \alpha, \mathrm{NR} 1 \mathrm{C} 1$ [59]), also decreased rat Abcc 2 protein levels by posttranscriptional mechanisms [68].

\section{Sequence variants of $\mathrm{ABCC} 2$ and the hereditary deficiency of $\mathrm{ABCC} 2$ in human Dubin-Johnson syndrome and in animal models}

More than 200 naturally occurring sequence variants have been identified in the exons, introns, and the 5'- and 3'flanking regions of the human $A B C C 2$ gene. Many of these sequence variants are single nucleotide changes in the introns or in the exons without leading to amino acid changes, and are, therefore, probably without functional consequences [62, 63, 117, 146, 162, 179] (single nucleotide polymorphism database, http://www.ncbi.nlm.nih.gov/ $\mathrm{SNP}$ ). Sequence variants that result in the absence of a functionally active $\mathrm{ABCC} 2$ protein from the canalicular membrane of hepatocytes are the molecular basis of DubinJohnson syndrome in humans [72, 82, 134, 170]. This syndrome is an autosomal, recessively inherited disorder characterized by conjugated hyperbilirubinemia (i.e., increased concentration of bilirubin glucuronosides in blood) and deposition of a dark pigment in hepatocytes, so that the liver of an affected individual appears dark blue or black $[31,145,158]$. The incidence of Dubin-Johnson syndrome ranges from 1:1,300 among Iranian Jews [152] to $1: 300,000$ in a Japanese population [70].

Sequence variants of the human $A B C C 2$ gene identified in patients with Dubin-Johnson syndrome include splicesite mutations resulting in exon loss and subsequent premature stop codons [70, 118, 168, 180], missense mutations [47, 111, 112, 117, 166, 168, 180, 181], a deletion mutation leading to the loss of two amino acids from the second nucleotide-binding domain [170], a deletion/in-frame insertion mutation [16], and nonsense mutations leading to premature stop codons [134, 154, 166] (Table 3, Fig. 2). Although all sequence variants associated with Dubin-Johnson syndrome result in the absence of a 
Table 3 Nucleotide sequence variants in the human $A B C C 2$ gene (NM_000392) leading to amino acid changes in the ABCC2/MRP2 protein (NP 000383)

\begin{tabular}{|c|c|c|c|c|c|c|c|}
\hline Location & $\begin{array}{l}\text { Nucleotide } \\
\text { change }^{a}\end{array}$ & $\begin{array}{l}\text { Deduced } \\
\text { effect on } \\
\text { protein }^{\mathrm{a}}\end{array}$ & $\begin{array}{l}\text { Causing } \\
\text { Dubin-- } \\
\text { Johnson } \\
\text { syndrome }^{\mathrm{b}}\end{array}$ & $\begin{array}{l}\text { Predicted } \\
\text { effect by } \\
\text { PolyPhen } \\
\text { database }^{\mathrm{c}}\end{array}$ & $\begin{array}{l}\text { Experimentally } \\
\text { proven } \\
\text { functional } \\
\text { consequence }\end{array}$ & $\begin{array}{l}\text { Average } \\
\text { frequency } \\
\text { of indicated } \\
\text { nucleotide } \\
\text { exchange in } \\
\text { population }\end{array}$ & $\begin{array}{l}\text { NCBI SNP } \\
\text { ID }^{\mathrm{d}} \text { and/or } \\
\text { references }\end{array}$ \\
\hline Exon 2 & c. $56 \mathrm{C}>\mathrm{T}^{\mathrm{e}}$ & p.P19L & & $\begin{array}{l}\text { Probably } \\
\text { damaging }\end{array}$ & & T: 0.007 & {$[63]$} \\
\hline Exon 2 & c. $116 \mathrm{~T}>\mathrm{A}$ & p.F39Y & & Benign & & $\begin{array}{l}\text { A: } 0.010 \\
\text { A: } 0.008\end{array}$ & $\begin{array}{l}\text { rs927344 } \\
\text { rs } 17222603\end{array}$ \\
\hline Exon 3 & c. $298 \mathrm{C}>\mathrm{T}$ & p.R100X $X^{f}$ & DJS & & & & {$[154]$} \\
\hline Exon 3 & c. $299 \mathrm{G}>\mathrm{A}^{\mathrm{e}}$ & p.R100Q & & $\begin{array}{l}\text { Possibly } \\
\text { damaging }\end{array}$ & & A: 0.007 & {$[63]$} \\
\hline Exon 7 & c. $736 \mathrm{~A}>\mathrm{C}$ & p.M246L & & Benign & & $\begin{array}{l}\text { C: } 0.002 \\
\text { C: } 0.002\end{array}$ & $\begin{array}{l}\text { rs } 8187667 \\
\text { rs } 17222744\end{array}$ \\
\hline Exon 7 & c. $842 \mathrm{G}>\mathrm{A}$ & p.S281N & & Benign & & $\begin{array}{l}\text { A: } 0.006- \\
0.056\end{array}$ & {$[117]$} \\
\hline Exon 8 & c. $998 \mathrm{~A}>\mathrm{G}$ & p.D333G & & $\begin{array}{l}\text { Possibly } \\
\text { damaging }\end{array}$ & & $\begin{array}{l}\text { G: } 0.002 \\
\text { G: } 0.004\end{array}$ & $\begin{array}{l}\text { rs8187668 } \\
\text { rs17222674 }\end{array}$ \\
\hline Exon 9 & c. $1058 \mathrm{G}>\mathrm{A}$ & p.R353H & & Benign & & $\begin{array}{l}\text { A: } 0.009 \\
\text { A: } 0.014\end{array}$ & $\begin{array}{l}\text { rs } 7080681 \\
\text { rs17216205 }\end{array}$ \\
\hline Exon 9 & c. $1177 \mathrm{C}>\mathrm{T}$ & p.R393W & DJS & $\begin{array}{l}\text { Probably } \\
\text { damaging }\end{array}$ & & & {$[104,112]$} \\
\hline Exon 10 & c. $1234 \mathrm{~A}>\mathrm{G}$ & p.R412G & & $\begin{array}{l}\text { Probably } \\
\text { damaging }\end{array}$ & $\begin{array}{l}\text { Deficient } \\
\text { methotrexate } \\
\text { transport } \\
\text { function }\end{array}$ & & {$[56]$} \\
\hline Exon 10 & c. $1249 \mathrm{G}>\mathrm{A}$ & p.V417I & & Benign & $\begin{array}{l}\text { None apparent } \\
{[50]}\end{array}$ & $\begin{array}{l}\text { A: } 0.163 \\
\text { A: } 0.158 \\
\text { A: } 0.125 \\
{[62]} \\
\text { A: } 0.183- \\
0.312 \\
{[117]}\end{array}$ & $\begin{array}{l}\text { rs2273697, } \\
{[146]} \\
\text { rs17216184 }\end{array}$ \\
\hline Exon 10 & c. $1457 \mathrm{C}>\mathrm{T}$ & p.T486I & & Benign & & $\begin{array}{l}\text { T: } 0.002 \\
\text { T: } 0.002\end{array}$ & $\begin{array}{l}\text { rs8187670 } \\
\text { rs17222589 }\end{array}$ \\
\hline Exon 11 & c. $1483 \mathrm{~A}>\mathrm{G}$ & p.K495E & & $\begin{array}{l}\text { Possibly } \\
\text { damaging }\end{array}$ & & $\begin{array}{l}\text { G: } 0.002 \\
\text { G: } 0.002\end{array}$ & $\begin{array}{l}\text { rs8187672 } \\
\text { rs17222561 }\end{array}$ \\
\hline Exon 13 & c. $1686 \mathrm{~T}>\mathrm{G}$ & p.F562L & & Benign & & $\begin{array}{l}\text { G: } 0.002 \\
\text { G: } 0.002\end{array}$ & $\begin{array}{l}\text { rs } 8187673 \\
\text { rs } 17216233\end{array}$ \\
\hline Exon 16 & c. $2009 \mathrm{~T}>\mathrm{C}$ & p.I670T & & Benign & & C: 0.006 & $\begin{array}{l}\mathrm{rs} 8187676 \\
\mathrm{rs} 17222632\end{array}$ \\
\hline Exon 16 & c. $2026 \mathrm{G}>\mathrm{C}$ & p.G676R & DJS & $\begin{array}{l}\text { Probably } \\
\text { damaging }\end{array}$ & & & [181] \\
\hline Exon 17 & c. $2125 \mathrm{~T}>\mathrm{C}$ & p.W709R & DJS & $\begin{array}{l}\text { Probably } \\
\text { damaging }\end{array}$ & & & [111] \\
\hline Exon 17 & c. $2153 \mathrm{~A}>\mathrm{G}$ & p.N718S & & $\begin{array}{l}\text { Possibly } \\
\text { damaging }\end{array}$ & & & rs3740072 \\
\hline Exon 17 & c. $2215 \mathrm{C}>\mathrm{T}$ & p.L739F & & $\begin{array}{l}\text { Probably } \\
\text { damaging }\end{array}$ & & T: 0.006 & {$[51]$} \\
\hline Exon 18 & c. $2302 \mathrm{C}>\mathrm{T}$ & p.R768W & DJS & $\begin{array}{l}\text { Probably } \\
\text { damaging }\end{array}$ & $\begin{array}{l}\text { Deficient } \\
\text { maturation } \\
\text { and impaired } \\
\text { sorting } \\
\text { [47] }\end{array}$ & $\begin{array}{c}\text { T: } 0.010 \\
{[62]}\end{array}$ & {$[168,180]$} \\
\hline
\end{tabular}

[47] 
Table 3 (continued)

\begin{tabular}{|c|c|c|c|c|c|c|c|}
\hline Location & $\begin{array}{l}\text { Nucleotide } \\
\text { change }^{\mathrm{a}}\end{array}$ & $\begin{array}{l}\text { Deduced } \\
\text { effect on } \\
\text { protein }^{\mathrm{a}}\end{array}$ & $\begin{array}{l}\text { Causing } \\
\text { Dubin-- } \\
\text { Johnson } \\
\text { syndrome }^{\mathrm{b}}\end{array}$ & $\begin{array}{l}\text { Predicted } \\
\text { effect by } \\
\text { PolyPhen } \\
\text { database }^{c}\end{array}$ & $\begin{array}{l}\text { Experimentally } \\
\text { proven } \\
\text { functional } \\
\text { consequence }\end{array}$ & $\begin{array}{l}\text { Average } \\
\text { frequency of } \\
\text { indicated } \\
\text { nucleotide } \\
\text { exchange in } \\
\text { population }\end{array}$ & $\begin{array}{l}\text { NCBI SNP } \\
\mathrm{ID}^{\mathrm{d}} \text { and/or } \\
\text { references }\end{array}$ \\
\hline Exon 18 & c. $2366 \mathrm{C}>\mathrm{T}$ & p.S789F & & $\begin{array}{l}\text { Probably } \\
\text { damaging }\end{array}$ & $\begin{array}{l}\text { Reduced } \\
\text { protein } \\
\text { levels [50] }\end{array}$ & $\begin{array}{l}\mathrm{T}: 0.010 \\
{[62]}\end{array}$ & \\
\hline Exon 19 & c. $2546 \mathrm{~T}>\mathrm{G}$ & p.L849R & & Benign & & $\begin{array}{l}\text { G: } 0.002 \\
\text { G: } 0.006\end{array}$ & $\begin{array}{l}\text { rs8187689 } \\
\text { rs17222617 }\end{array}$ \\
\hline Exon 20 & c. $2647 \mathrm{G}>\mathrm{A}^{\mathrm{e}}$ & p.D883N & & Benign & & A: 0.007 & {$[63]$} \\
\hline Exon 20 & c. $2677 \mathrm{G}>\mathrm{C}$ & p.E893Q & & Benign & & & rs 3740071 \\
\hline Exon 21 & c. $2882 \mathrm{~A}>\mathrm{G}^{\mathrm{e}}$ & p.K961R & & Benign & & G: 0.007 & {$[63]$} \\
\hline Exon 22 & c. $2901 \mathrm{C}>\mathrm{A}$ & p.Y967X & & & & $\begin{array}{l}\text { A: } 0.002 \\
\text { A: } 0.002\end{array}$ & $\begin{array}{l}\text { rs8187683 } \\
\text { rs } 17222547\end{array}$ \\
\hline Exon 22 & c. $2944 \mathrm{~A}>\mathrm{G}$ & p.I982V & & Benign & & $\begin{array}{l}\text { G: } 0.002 \\
\text { G: } 0.002\end{array}$ & $\begin{array}{l}\text { rs8187684 } \\
\text { rs17222554 }\end{array}$ \\
\hline Exon 22 & c. $3057 \mathrm{G}>\mathrm{T}^{\mathrm{e}}$ & p.Q1019H & & Benign & & T: 0.007 & {$[63]$} \\
\hline Exon 23 & c. $3107 \mathrm{~T}>\mathrm{C}$ & p.I1036T & & $\begin{array}{l}\text { Possibly } \\
\text { damaging }\end{array}$ & & $\begin{array}{l}C: 0.002 \\
C: 0.004\end{array}$ & $\begin{array}{l}\text { rs8187685 } \\
\text { rs17216149 }\end{array}$ \\
\hline Exon 23 & c. $3188 \mathrm{~A}>\mathrm{G}$ & p.N1063S & & Benign & & $\begin{array}{l}\text { G: } 0.002 \\
\text { G: } 0.002\end{array}$ & $\begin{array}{l}\text { rs8187686 } \\
\text { rs17222540 }\end{array}$ \\
\hline Exon 23 & c. $3196 \mathrm{C}>\mathrm{T}$ & p.R1066 ${ }^{f}$ & DJS & & $\begin{array}{l}\text { No ABCC2 } \\
\text { protein } \\
\text { in liver }\end{array}$ & & {$[134]$} \\
\hline Exon 25 & c. $3449 \mathrm{G}>\mathrm{A}$ & p.R1150H & DJS & $\begin{array}{l}\text { Probably } \\
\text { damaging }\end{array}$ & $\begin{array}{l}\text { Deficient } \\
\text { transport } \\
\text { function }\end{array}$ & $\begin{array}{l}\text { A: } 0- \\
0.009\end{array}$ & [117] \\
\hline Exon 25 & c. $3517 \mathrm{~A}>\mathrm{T}$ & p.I1173F & DJS & $\begin{array}{l}\text { Probably } \\
\text { damaging }\end{array}$ & $\begin{array}{l}\text { Deficient } \\
\text { maturation } \\
\text { and impaired } \\
\text { sorting, } \\
\text { deficient } \\
\text { transport } \\
\text { function }\end{array}$ & $\begin{array}{c}\text { T: } 0- \\
0.029 \\
{[117]}\end{array}$ & {$[80,117]$} \\
\hline Exon 25 & c. $3521 \mathrm{G}>\mathrm{A}^{\mathrm{e}}$ & p.R1174H & & $\begin{array}{l}\text { Probably } \\
\text { damaging }\end{array}$ & & A: 0.007 & [63] \\
\hline Exon 25 & c. $3542 \mathrm{G}>\mathrm{T}$ & p.R1181L & & $\begin{array}{l}\text { Possibly } \\
\text { damaging }\end{array}$ & & $\begin{array}{l}\text { T: } 0.039 \\
\text { T: } 0.034\end{array}$ & $\begin{array}{l}\text { rs8187692 } \\
\text { rs17222702 }\end{array}$ \\
\hline Exon 25 & c. $3563 \mathrm{~T}>\mathrm{A}$ & p.V1188E & & Benign & & $\begin{array}{l}\text { A: } 0.059 \\
\text { A: } 0.059\end{array}$ & $\begin{array}{l}\text { rs8187694 } \\
\text { rs17222723 }\end{array}$ \\
\hline Exon 26 & c. $3732 \mathrm{~T}>\mathrm{G}^{\mathrm{e}}$ & p.N1244K & & $\begin{array}{l}\text { Possibly } \\
\text { damaging }\end{array}$ & & G: 0.014 & {$[63]$} \\
\hline Exon 27 & c. $3817 \quad A>G$ & p.T1273A & & Benign & & $\begin{array}{l}\text { G: } 0.002 \\
\text { G: } 0.004\end{array}$ & $\begin{array}{l}\text { rs8187699 } \\
\text { rs17222582 }\end{array}$ \\
\hline Exon 27 & c. $3825 \mathrm{C}>\mathrm{G}$ & p.Y1275X $X^{f}$ & DJS & & $\begin{array}{l}\text { No ABCC2 } \\
\text { protein } \\
\text { in liver }\end{array}$ & & {$[104]$} \\
\hline Exon 28 & c. $3872 \mathrm{C}>\mathrm{T}$ & p.P1291L & & $\begin{array}{l}\text { Possibly } \\
\text { damaging }\end{array}$ & & $\begin{array}{l}\text { T: } 0.012 \\
\text { T: } 0.010\end{array}$ & $\begin{array}{l}\text { rs } 8187700 \\
\text { rs } 17216317\end{array}$ \\
\hline Exon 28 & c. $3895 \mathrm{~A}>\mathrm{C}$ & p.K1299Q & & Benign & & & $\begin{array}{l}\text { rs4148400, } \\
{[146]}\end{array}$ \\
\hline Exon 28 & c. $3928 \mathrm{C}>\mathrm{T}$ & p.R1310X ${ }^{f}$ & DJS & & & & {$[166]$} \\
\hline Exon 29 & c. $4100 \mathrm{C}>\mathrm{G}^{\mathrm{e}}$ & p.S1367C & & $\begin{array}{l}\text { Possibly } \\
\text { damaging }\end{array}$ & & G: 0.007 & [63] \\
\hline Exon 29 & c. $4145 \mathrm{~A}>\mathrm{G}$ & p.Q1382R & DJS & Probably & Deficient & & {$[47,168]$} \\
\hline
\end{tabular}


Table 3 (continued)

\begin{tabular}{|c|c|c|c|c|c|c|c|}
\hline Location & $\begin{array}{l}\text { Nucleotide } \\
\text { change }^{\text {a }}\end{array}$ & $\begin{array}{l}\text { Deduced } \\
\text { effect on } \\
\text { protein }^{\mathrm{a}}\end{array}$ & $\begin{array}{l}\text { Causing } \\
\text { Dubin-- } \\
\text { Johnson } \\
\text { syndrome }^{\mathrm{b}}\end{array}$ & $\begin{array}{l}\text { Predicted } \\
\text { effect by } \\
\text { PolyPhen } \\
\text { database }^{c}\end{array}$ & $\begin{array}{l}\text { Experimentally } \\
\text { proven } \\
\text { functional } \\
\text { consequence }\end{array}$ & $\begin{array}{l}\text { Average } \\
\text { frequency of } \\
\text { indicated } \\
\text { nucleotide } \\
\text { exchange in } \\
\text { population }\end{array}$ & $\begin{array}{l}\text { NCBI SNP } \\
\mathrm{ID}^{\mathrm{d}} \text { and/or } \\
\text { references }\end{array}$ \\
\hline & & & & damaging & $\begin{array}{l}\text { transport } \\
\text { function [47] }\end{array}$ & & \\
\hline Exon 30 & c. $4175 \_4180$ del 6 & p.R1392_M1393del2 & DJS & & $\begin{array}{l}\text { No ABCC2 } \\
\text { protein } \\
\text { in liver [170] } \\
\text { Impaired } \\
\text { sorting and } \\
\text { trafficking } \\
\text { [79] }\end{array}$ & & {$[79,170]$} \\
\hline Exon 31 & c. $4348 \mathrm{G}>\mathrm{A}$ & p.A1450T & & $\begin{array}{l}\text { Possibly } \\
\text { damaging }\end{array}$ & $\begin{array}{l}\text { Reduced } \\
\text { protein } \\
\text { levels }[50]\end{array}$ & $\begin{array}{l}\mathrm{T}: 0.010 \\
{[62]}\end{array}$ & {$[62]$} \\
\hline Exon 31 & c. $4430 \mathrm{C}>\mathrm{T}$ & p.T1477M & & Benign & & T: 0.006 & [51] \\
\hline \multirow[t]{2}{*}{ Exon 32} & c. $4544 \mathrm{G}>\mathrm{A}$ & p.C1515Y & & Benign & & A: 0.047 & rs 8187710 \\
\hline & & & & & & A: 0.116 & rs 17222568 \\
\hline
\end{tabular}

NCBI National Center for Biotechnology Information, SNP single nucleotide polymorphism, DJS Dubin-Johnson syndrome

${ }^{a}$ As recommended by the Human Genome Variation Society (http://www.hgvs.org/mutnomen) and by ref [26], nucleotide position +1 is the A of the ATG of the translation initiation codon in the $A B C C 2$ cDNA sequence, "c." describes a nucleotide change in relation to the $A B C C 2$ cDNA sequence, "p." describes a change in relation to the deduced ABCC2 protein sequence, and "X" denotes a premature stop codon

b If not indicated otherwise, the diagnosis of Dubin-Johnson syndrome was based on the histopathology of the liver and on elevated serum levels of conjugated bilirubin

${ }^{c}$ PolyPhen online tool for assessing potential effects of amino acid substitutions, http://genetics.bwh.harvard.edu/pph

${ }^{\mathrm{d}}$ Single nucleotide polymorphism database, http://www.ncbi.nlm.nih.gov/SNP; data based on NCBI dbSNP build 125, regular updates available

${ }^{\mathrm{e}}$ Identified in cell lines derived from Japanese individuals

${ }^{\mathrm{f}}$ Probably reduced $A B C C 2 \mathrm{mRNA}$ levels due to nonsense-mediated mRNA decay [167]

functionally active $\mathrm{ABCC} 2$ protein from the canalicular membrane, their effects on the synthesis and function of the ABCC2 protein differ. Premature stop codons may cause rapid degradation of the mutated $A B C C 2$ mRNA by nonsense-mediated decay, a mechanism which cotranslationally recognizes when a stop codon precedes the last splice-site [167], thus leading to the absence of the ABCC2 protein in some cases of Dubin-Johnson syndrome. In fact, a truncated $\mathrm{ABCC} 2$ protein has not been detected so far [134, 170]. Other Dubin-Johnson syndrome-associated sequence variants lead to deficient maturation and impaired sorting of the $\mathrm{ABCC} 2$ protein or to an apically localized, but functionally inactive, $\mathrm{ABCC} 2$ protein $[47,79,80,117]$ (Table 3).

Many naturally occurring sequence variants have been identified whose consequences on $\mathrm{ABCC} 2$ function are not yet known (Table 3). The potential effects of these single amino acid substitutions can be tentatively assessed by the online tool Polymorphism Phenotyping (PolyPhen, http://genetics.bwh.harvard.edu/pph [138]). Interestingly, all amino acid substitutions causing Dubin-Johnson syndrome are classified in this database as "probably damaging" (Table 3). However, the PolyPhen tool cannot replace the experimental analysis of each individual amino acid substitution to proof changes of $\mathrm{ABCC} 2$ function, as exemplified by some published transfection studies [79, 80,117].

Two different mutant hyperbilirubinemic rat strains, the GY/TR ${ }^{-}$rats [64] and the Eisai hyperbilirubinemic rats (EHBR) [54, 163], have a hereditary defect in the secretion of anionic conjugates into bile. In consequence of the molecular identification and cloning of rat Abcc2 as the apical conjugate efflux pump [13, 60, 133], which is defective in these rat strains $[13,60,133]$, both can now be considered as animal models of human Dubin-Johnson syndrome. Two distinct naturally occurring sequence variants in the rat $A b c c 2$ gene, either at codon 401 (GY/ $\mathrm{TR}^{-}$) [133] or at codon 855 (EHBR) [60], lead to premature stop codons and to a lack of the Abcc2 protein from the hepatocyte canalicular membrane [13, 114, 133]. Recently, Abcc2-knock-out mice have been generated and characterized by several groups [18, 121, 177]. These Abcc2deficient mice are apparently healthy and fertile, as are 
the Abcc2-deficient rats. It will be of interest to crossbreed these mutants with mice lacking other Abc transporters, such as knock-out mice lacking Abcc3, Abcc4, Abcb1a and Abcb1b (Mdr1a and Mdr1b Pglycoprotein), and Abcg2 (Bcrp1).

Acknowledgements The work in the authors' laboratory was supported by the German Cancer Research Center, by the Deutsche Forschungsgemeinschaft, Bonn, Germany, and the Wilhelm SanderStiftung, München, Germany. We acknowledge the contributions to this work by past and present members of the Division of Tumor Biochemistry, particularly from Jörg König, Markus Büchler, Yunhai Cui, Verena Keitel, Rosemarie Mayer, Wolfgang Hagmann, Manuela Brom, Hiroyuki Tsujii, Daniel Rost, Thomas Schaub, Kathrin Kopplow-de Jong, Inka Leier, and Gabriele Jedlitschky, as well as the collaboration with Jürgen Kartenbeck and Herbert Spring from the Cell Biology Division of the German Cancer Research Center.

\section{References}

1. Akita H, Suzuki H, Ito K, Kinoshita S, Sato N, Takikawa H, Sugiyama Y (2001) Characterization of bile acid transport mediated by multidrug resistance associated protein 2 and bile salt export pump. Biochim Biophys Acta 1511:7-16

2. Aronica E, Gorter JA, Ramkema M, Redeker S, Ozbas-Gerceker F, van Vliet EA, Scheffer GL, Scheper RJ, van der Valk P, Baayen JC, Troost D (2004) Expression and cellular distribution of multidrug resistance-related proteins in the hippocampus of patients with mesial temporal lobe epilepsy. Epilepsia 45: 441-451

3. Arts HJ, Katsaros D, de Vries EG, Massobrio M, Genta F, Danese S, Arisio R, Scheper RJ, Kool M, Scheffer GL, Willemse PH, van der Zee AG, Suurmeijer AJ (1999) Drug resistanceassociated markers P-glycoprotein, multidrug resistance-associated protein 1 , multidrug resistance-associated protein 2 , and lung resistance protein as prognostic factors in ovarian carcinoma. Clin Cancer Res 5:2798-2805

4. Bakos E, Evers R, Sinko E, Varadi A, Borst P, Sarkadi B (2000) Interactions of the human multidrug resistance proteins MRP1 and MRP2 with organic anions. Mol Pharmacol 57:760-768

5. Bart J, Hollema H, Groen HJ, de Vries EG, Hendrikse NH, Sleijfer DT, Wegman TD, Vaalburg W, van der Graaf WT (2004) The distribution of drug-efflux pumps, P-gp, BCRP, MRP1 and MRP2, in the normal blood-testis barrier and in primary testicular tumours. Eur J Cancer 40:2064-2070

6. Beck K, Hayashi K, Dang K, Hayashi M, Boyd CD (2005) Analysis of ABCC6 (MRP6) in normal human tissues. Histochem Cell Biol 123:517-528

7. Beuers U, Bilzer M, Chittattu A, Kullak-Ublick GA, Keppler D, Paumgartner G, Dombrowski F (2001) Tauroursodeoxycholic acid inserts the apical conjugate export pump, Mrp2, into canalicular membranes and stimulates organic anion secretion by protein kinase C-dependent mechanisms in cholestatic rat liver. Hepatology 33:1206-1216

8. Blumberg B, Sabbagh W Jr, Juguilon H, Bolado J Jr, van Meter CM, Ong ES, Evans RM (1998) SXR, a novel steroid and xenobiotic-sensing nuclear receptor. Genes Dev 12:3195-3205

9. Bock KW, Eckle T, Ouzzine M, Fournel-Gigleux S (2000) Coordinate induction by antioxidants of UDP-glucuronosyltransferase UGT1A6 and the apical conjugate export pump MRP2 (multidrug resistance protein 2) in Caco-2 cells. Biochem Pharmacol 59:467-470

10. Bretscher A, Chambers D, Nguyen R, Reczek D (2000) ERM-Merlin and EBP50 protein families in plasma membrane organization and function. Annu Rev Cell Dev Biol $16: 113-143$

11. Broeks A, Gerrard B, Allikmets R, Dean M, Plasterk RHA (1996) Homologues of the human multidrug resistance genes MRP and MDR contribute to heavy metal resistance in the soil nematode Caenorhabditis elegans. EMBO J 15:6132-6143

12. Bronger H, König J, Kopplow K, Steiner HH, Ahmadi R, Herold-Mende C, Keppler D, Nies AT (2005) ABCC drug efflux pumps and organic anion uptake transporters in human gliomas and the blood-tumor barrier. Cancer Res 65:11419-11428

13. Büchler M, König J, Brom M, Kartenbeck J, Spring H, Horie T, Keppler D (1996) cDNA cloning of the hepatocyte canalicular isoform of the multidrug resistance protein, cMRP, reveals a novel conjugate export pump deficient in hyperbilirubinemic mutant rats. J Biol Chem 271:15091-15098

14. Cantz T, Nies AT, Brom M, Hofmann AF, Keppler D (2000) MRP2, a human conjugate export pump, is present and transports Fluo-3 into apical vacuoles of HepG2 cells. Am J Physiol Gasterointest Liver Physiol 278:G522-G531

15. Cao J, Stieger B, Meier PJ, Vore M (2002) Expression of rat hepatic multidrug resistance-associated proteins and organic anion transporters in pregnancy. Am J Physiol Gasterointest Liver Physiol 283:G757-G766

16. Cebecauerova D, Jirasek T, Budisova L, Mandys V, Volf V, Novotna Z, Subhanova I, Hrebicek M, Elleder M, Jirsa M (2005) Dual hereditary jaundice: simultaneous occurrence of mutations causing Gilbert's and Dubin-Johnson syndrome. Gastroenterology 129:315-320

17. Chen ZS, Kawabe T, Ono M, Aoki S, Sumizawa T, Furukawa T, Uchiumi T, Wada M, Kuwano M, Akiyama SI (1999) Effect of multidrug resistance-reversing agents on transporting activity of human canalicular multispecific organic anion transporter. Mol Pharmacol 56:1219-1228

18. Chu X, Strauss JR, Mariano MA, Li J, Newton DJ, Cai X, Wang RW, Yabut J, Hartley DP, Evans DC, Evers R (2006) Characterization of mice lacking the multidrug resistance protein Mrp2 (Abcc2). J Pharmacol Exp Ther 317:579-589

19. Chu XY, Kato Y, Niinuma K, Sudo KI, Hakusui H, Sugiyama Y (1997) Multispecific organic anion transporter is responsible for the biliary excretion of the camptothecin derivative irinotecan and its metabolites in rats. J Pharmacol Exp Ther 281:304-314

20. Chu XY, Huskey SE, Braun MP, Sarkadi B, Evans DC, Evers R (2004) Transport of ethinylestradiol glucuronide and ethinylestradiol sulfate by the multidrug resistance proteins MRP1, MRP2, and MRP3. J Pharmacol Exp Ther 309:156-164

21. Cole SPC, Bhardwaj G, Gerlach JH, Mackie JE, Grant CE, Almquist KC, Stewart AJ, Kurz EU, Duncan AMV, Deeley RG (1992) Overexpression of a transporter gene in a multidrugresistant human lung cancer cell line. Science 258:1650-1654

22. Conrad S, Viertelhaus A, Orzechowski A, Hoogstraate J, Gjellan K, Schrenk D, Kauffmann HM (2001) Sequencing and tissue distribution of the canine MRP2 gene compared with MRP1 and MDR1. Toxicology 156:81-91

23. Courtois A, Payen L, Vernhet L, Morel F, Guillouzo A, Fardel O (1999) Differential regulation of canalicular multispecific organic anion transporter (cMOAT) expression by the chemopreventive agent oltipraz in primary rat hepatocytes and in rat liver. Carcinogenesis 20:2327-2330

24. Cui Y, König J, Buchholz U, Spring H, Leier I, Keppler D (1999) Drug resistance and ATP-dependent conjugate transport mediated by the apical multidrug resistance protein, MRP2, 
permanently expressed in human and canine cells. Mol Pharmacol 55:929-937

25. Cui Y, König J, Keppler D (2001) Vectorial transport by doubletransfected cells expressing the human uptake transporter SLC21A8 and the apical export pump ABCC2. Mol Pharmacol 60:934-943

26. den Dunnen JT, Antonarakis SE (2000) Mutation nomenclature extensions and suggestions to describe complex mutations: a discussion. Human Mutat 15:7-12

27. Denson LA, Bohan A, Held MA, Boyer JL (2002) Organ-specific alterations in RAR alpha:RXR alpha abundance regulate rat Mrp2 (Abcc2) expression in obstructive cholestasis. Gastroenterology 123:599-607

28. Dietrich CG, Geier A, Salein N, Lammert F, Roeb E, Oude Elferink RP, Matern S, Gartung C (2004) Consequences of bile duct obstruction on intestinal expression and function of multidrug resistance-associated protein 2. Gastroenterology 126:1044-1053

29. Dombrowski F, Kubitz R, Chittattu A, Wettstein M, Saha N, Häussinger D (2000) Electron-microscopic demonstration of multidrug resistance protein 2 (Mrp2) retrieval from the canalicular membrane in response to hyperosmolarity and lipopolysaccharide. Biochem J 348:183-188

30. Donner MG, Keppler D (2001) Up-regulation of basolateral multidrug resistance protein $3(\mathrm{Mrp} 3)$ in cholestatic rat liver. Hepatology 34:351-359

31. Dubin IN, Johnson FB (1954) Chronic idiopathic jaundice with unidentified pigment in liver cells; a new clinicopathologic entity with report of 12 cases. Medicine (Baltimore) $33: 155-179$

32. Evers R, Kool M, van Deemter L, Janssen H, Calafat J, Oomen LCJM, Paulusma CC, Oude Elferink RPJ, Baas F, Schinkel AH, Borst P (1998) Drug export activity of the human canalicular multispecific organic anion transporter in polarized kidney MDCK cells expressing cMOAT (MRP2) cDNA. J Clin Invest 101:1310-1319

33. Falk E, Müller M, Huber M, Keppler D, Kurz G (1989) Direct photoaffinity labeling of leukotriene binding sites. Eur J Biochem 186:741-747

34. Fernandez SB, Hollo Z, Kern A, Bakos E, Fischer PA, Borst P, Evers R (2002) Role of the N-terminal transmembrane region of the multidrug resistance protein MRP2 in routing to the apical membrane in MDCKII cells. J Biol Chem 277:31048-31055

35. Fernandez-Checa JC, Takikawa H, Horie T, Ookhtens $M$, Kaplowitz N (1992) Canalicular transport of reduced glutathione in normal and mutant Eisai hyperbilirubinemic rats. J Biol Chem 267:1667-1673

36. Fickert P, Zollner G, Fuchsbichler A, Stumptner C, Pojer C, Zenz R, Lammert F, Stieger B, Meier PJ, Zatloukal K, Denk H, Trauner M (2001) Effects of ursodeoxycholic and cholic acid feeding on hepatocellular transporter expression in mouse liver. Gastroenterology 121:170-183

37. Fritz F, Chen J, Hayes P, Sirotnak FM (2000) Molecular cloning of the murine cMOAT ATPase. Biochim Biophys Acta 1492:531-536

38. Fromm MF, Kauffmann HM, Fritz P, Burk O, Kroemer HK, Warzok RW, Eichelbaum M, Siegmund W, Schrenk D (2000) The effect of rifampin treatment on intestinal expression of human MRP transporters. Am J Pathol 157:1575-1580

39. Gao M, Yamazaki M, Loe DW, Westlake CJ, Grant CE, Cole SP, Deeley RG (1998) Multidrug resistance protein. Identification of regions required for active transport of leukotriene $\mathrm{C}_{4}$. J Biol Chem 273:10733-10740

40. Gerk PM, Vore M (2002) Regulation of expression of the multidrug resistance-associated protein 2 (MRP2) and its role in drug disposition. J Pharmacol Exp Ther 302:407-415
41. Goodwin B, Hodgson E, Liddle C (1999) The orphan human pregnane $\mathrm{X}$ receptor mediates the transcriptional activation of CYP3A4 by rifampicin through a distal enhancer module. Mol Pharmacol 56:1329-1339

42. Hagenbuch N, Reichel C, Stieger B, Cattori V, Fattinger KE, Landmann L, Meier PJ, Kullak-Ublick GA (2001) Effect of phenobarbital on the expression of bile salt and organic anion transporters of rat liver. J Hepatol 34:881-887

43. Hagmann W, Nies AT, König J, Frey M, Zentgraf H, Keppler D (1999) Purification of the human apical conjugate export pump MRP2. Reconstitution and functional characterization as substrate-stimulated ATPase. Eur J Biochem 265:281-289

44. Hagmann W, Schubert J, König J, Keppler D (2002) Reconstitution of transport-active multidrug resistance protein 2 (MRP2; ABCC2) in proteoliposomes. Biol Chem 383:1001-1009

45. Haimeur A, Conseil G, Deeley RG, Cole SP (2004) The MRPrelated and $\mathrm{BCRP} / \mathrm{ABCG} 2$ multidrug resistance proteins: biology, substrate specificity and regulation. Curr Drug Metab 5:21-53

46. Harris MJ, Kuwano M, Webb M, Board PG (2001) Identification of the apical membrane-targeting signal of the multidrug resistance-associated protein 2 (MRP2/MOAT). J Biol Chem 276:20876-20881

47. Hashimoto K, Uchiumi T, Konno T, Ebihara T, Nakamura T, Wada M, Sakisaka S, Maniwa F, Amachi T, Ueda K, Kuwano M (2002) Trafficking and functional defects by mutations of the ATP-binding domains in MRP2 in patients with Dubin-Johnson syndrome. Hepatology 36:1236-1245

48. Hegedus T, Sessler T, Scott R, Thelin W, Bakos E, Varadi A, Szabo K, Homolya L, Milgram SL, Sarkadi B (2003) C-terminal phosphorylation of MRP2 modulates its interaction with PDZ proteins. Biochem Biophys Res Commun 302:454-461

49. Hinoshita E, Uchiumi T, Taguchi K, Kinukawa N, Tsuneyoshi M, Maehara Y, Sugimachi K, Kuwano M (2000) Increased expression of an ATP-binding cassette superfamily transporter, multidrug resistance protein 2 , in human colorectal carcinomas. Clin Cancer Res 6:2401-2407

50. Hirouchi M, Suzuki H, Itoda M, Ozawa S, Sawada J, Ieiri I, Ohtsubo K, Sugiyama Y (2004) Characterization of the cellular localization, expression level, and function of SNP variants of MRP2/ABCC2. Pharm Res 21:742-748

51. Ho RH, Kim RB (2003) Identification of novel single nucleotide polymorphisms in the multidrug resistance-associated protein 2 (MRP2). Proc Am Assoc Cancer Res 44:4663 (abstract)

52. Hoffmann K, Gastens AM, Volk HA, Loscher W (2006) Expression of the multidrug transporter MRP2 in the bloodbrain barrier after pilocarpine-induced seizures in rats. Epilepsy Res 69:1-14

53. Hooijberg JH, Broxterman HJ, Kool M, Assaraf YG, Peters GJ, Noordhuis P, Scheper RJ, Borst P, Pinedo HM, Jansen G (1999) Antifolate resistance mediated by the multidrug resistance proteins MRP1 and MRP2. Cancer Res 59:2532-2535

54. Hosokawa S, Tagaya O, Mikami T, Nozaki Y, Kawaguchi A, Yamatsu K, Shamoto M (1992) A new rat mutant with chronic conjugated hyperbilirubinemia and renal glomerular lesions. Lab Anim Sci 42:27-34

55. Huber M, Guhlmann A, Jansen PL, Keppler D (1987) Hereditary defect of hepatobiliary cysteinyl leukotriene elimination in mutant rats with defective hepatic anion excretion. Hepatology 7:224-228

56. Hulot JS, Villard E, Maguy A, Morel V, Mir L, Tostivint I, William-Faltaos D, Fernandez C, Hatem S, Deray G, Komajda M, Leblond V, Lechat P (2005) A mutation in the drug transporter gene $\mathrm{ABCC} 2$ associated with impaired methotrexate elimination. Pharmacogenet Genomics 15:277-285 
57. Ishikawa T, Müller M, Klünemann C, Schaub T, Keppler D (1990) ATP-dependent primary active transport of cysteinyl leukotrienes across liver canalicular membrane: role of the ATPdependent transport system for glutathione S-conjugates. J Biol Chem 265:19279-19286

58. Ishizuka H, Konno K, Naganuma H, Sasahara K, Kawahara Y, Niinuma K, Suzuki H, Sugiyama Y (1997) Temocaprilat, a novel angiotensin-converting enzyme inhibitor, is excreted in bile via an ATP-dependent active transporter (cMOAT) that is deficient in Eisai hyperbilirubinemic mutant rats (EHBR). J Pharmacol Exp Ther 280:1304-1311

59. Issemann I, Prince RA, Tugwood JD, Green S (1993) The peroxisome proliferator-activated receptor:retinoid $\mathrm{X}$ receptor heterodimer is activated by fatty acids and fibrate hypolipidaemic drugs. J Mol Endocrinol 11:37-47

60. Ito K, Suzuki H, Hirohashi T, Kume K, Shimizu T, Sugiyama Y (1997) Molecular cloning of canalicular multispecific organic anion transporter defective in EHBR. Am J Physiol 272:G16-G22

61. Ito K, Suzuki H, Hirohashi T, Kume K, Shimizu T, Sugiyama Y (1998) Functional analysis of a canalicular multispecific organic anion transporter cloned from rat liver. J Biol Chem 273:1684-1688

62. Ito S, Ieiri I, Tanabe M, Suzuki A, Higuchi S, Otsubo K (2001) Polymorphisms of the ABC transporter genes, MDR1, MRP1 and MRP2/cMOAT, in healthy Japanese subjects. Pharmacogenetics 11:175-184

63. Itoda M, Saito Y, Soyama A, Saeki M, Murayama N, Ishida S, Sai K, Nagano M, Suzuki H, Sugiyama Y, Ozawa S, Sawada J (2002) Polymorphisms in the ABCC2 (cMOAT/MRP2) gene found in 72 established cell lines derived from Japanese individuals: an association between single nucleotide polymorphisms in the $5^{\prime}$-untranslated region and exon 28. Drug Metab Dispos 30:363-364

64. Jansen PLM, Peters WHM, Lamers WH (1985) Hereditary chronic conjugated hyperbilirubinemia in mutants rats caused by defective hepatic anion transport. Hepatology 5:573-579

65. Jedlitschky G, Keppler D (2002) Transport of leukotriene C4 and structurally related conjugates. Vitam Horm 64:153-184

66. Jedlitschky G, Leier I, Buchholz U, Center M, Keppler D (1994) ATP-dependent transport of glutathione S-conjugates by the multidrug resistance-associated protein. Cancer Res $54: 4833-4836$

67. Jedlitschky G, Leier I, Buchholz U, Hummel-Eisenbeiss J, Burchell B, Keppler D (1997) ATP-dependent transport of bilirubin glucuronides by the multidrug resistance protein MRP1 and its hepatocyte canalicular isoform MRP2. Biochem J 327:305-310

68. Johnson DR, Klaassen CD (2002) Regulation of rat multidrug resistance protein 2 by classes of prototypical microsomal enzyme inducers that activate distinct transcription pathways. Toxicol Sci 67:182-189

69. Jones BR, Li W, Cao J, Hoffman TA, Gerk PM, Vore M (2005) The role of protein synthesis and degradation in the posttranscriptional regulation of rat multidrug resistance-associated protein 2 (Mrp2, Abcc2). Mol Pharmacol 68:701-710

70. Kajihara S, Hisatomi A, Mizuta T, Hara T, Ozaki I, Wada I, Yamamoto K (1998) A splice mutation in the human canalicular multispecific organic anion transporter gene causes Dubin-Johnson syndrome. Biochem Biophys Res Comm 253:454-457

71. Kamisako T, Leier I, Cui Y, König J, Buchholz U, HummelEisenbeiss J, Keppler D (1999) Transport of monoglucuronosyl and bisglucuronosyl bilirubin by recombinant human and rat multidrug resistance protein 2. Hepatology 30:485-490

72. Kartenbeck J, Leuschner U, Mayer R, Keppler D (1996) Absence of the canalicular isoform of the MRP gene-encoded conjugate export pump from the hepatocytes in Dubin-Johnson syndrome. Hepatology 23:1061-1066

73. Kast HR, Goodwin B, Tarr PT, Jones SA, Anisfeld AM, Stoltz CM, Tontonoz P, Kliewer S, Willson TM, Edwards PA (2002) Regulation of multidrug resistance-associated protein 2 (ABCC2) by the nuclear receptors pregnane $\mathrm{X}$ receptor, farnesoid $\mathrm{X}$ activated receptor, and constitutive androstane receptor. J Biol Chem 277:2908-2915

74. Kauffmann HM, Schrenk D (1998) Sequence analysis and functional characterization of the 5'-flanking region of the rat multidrug resistance protein 2 (mrp2) gene. Biochem Biophys Res Commun 245:325-331

75. Kauffmann HM, Keppler D, Kartenbeck J, Schrenk D (1997) Induction of cMrp/cMoat gene expression by cisplatin, 2acetylaminofluorene, or cycloheximide in rat hepatocytes. Hepatology 26:980-985

76. Kauffmann HM, Keppler D, Gant TW, Schrenk D (1998) Induction of hepatic mrp2 (cmrp/cmoat) gene expression in nonhuman primates treated with rifampicin or tamoxifen. Arch Toxicol 72:763-768

77. Kawabata Y, Kamada E, Furuta S, Takei M, Kurimoto T, Okudaira K, Nishigaki R (2004) ATP-dependent transport of a novel thromboxane A2 receptor antagonist, [2-(4-chlorophenylsulfonylaminomethyl)indan-5-yl]acetate (Z-335) and its xenobiotic taurine conjugate (Z-335-Tau) by rat bile canalicular membrane vesicles. Pharm Res 21:467-475

78. Kawabe T, Chen ZS, Wada M, Uchiumi T, Ono M, Akiyama S, Kuwano M (1999) Enhanced transport of anticancer agents and leukotriene $\mathrm{C} 4$ by the human canalicular multispecific organic anion transporter (cMOAT/MRP2). FEBS Lett 456:327-331

79. Keitel V, Kartenbeck J, Nies AT, Spring H, Brom M, Keppler D (2000) Impaired protein maturation of the conjugate export pump multidrug resistance protein 2 as a consequence of a deletion mutation in Dubin-Johnson syndrome. Hepatology 32:1317-1328

80. Keitel V, Nies AT, Brom M, Hummel-Eisenbeiss J, Spring H, Keppler D (2003) A common Dubin-Johnson syndrome mutation impairs protein maturation and transport activity of MRP2 (ABCC2). Am J Physiol Gasterointest Liver Physiol 284:G165-G174

81. Keppler D (2005) Uptake and efflux transporters for conjugates in human hepatocytes. Methods Enzymol 400:531-542

82. Keppler D, Kartenbeck J (1996) The canalicular conjugate export pump encoded by the cmrp/cmoat gene. In: Boyer JL, Ockner RK (eds) Progress in liver diseases. Saunders, Philadelphia, pp 55-67

83. Keppler D, König J (1997) Expression and localization of the conjugate export pump encoded by the MRP2 (cMRP/cMOAT) gene in liver. FASEB J 11:509-516

84. Kikuchi S, Hata M, Fukumoto K, Yamane Y, Matsui T, Tamura A, Yonemura S, Yamagishi H, Keppler D, Tsukita S (2002) Radixin deficiency causes conjugated hyperbilirubinemia with loss of Mrp2 from bile canalicular membranes. Nat Genet 31:320-325

85. Kliewer SA, Moore JT, Wade L, Staudinger JL, Watson MA, Jones SA, McKee DD, Oliver BB, Willson TM, Zetterstrom RH, Perlmann T, Lehmann JM (1998) An orphan nuclear receptor activated by pregnanes defines a novel steroid signaling pathway. Cell 92:73-82

86. Kocher O, Comella N, Gilchrist A, Pal R, Tognazzi K, Brown LF, Knoll JH (1999) PDZK1, a novel PDZ domain-containing protein up-regulated in carcinomas and mapped to chromosome 1q21, interacts with cMOAT (MRP2), the multidrug resistanceassociated protein. Lab Invest 79:1161-1170 
87. Kocher O, Pal R, Roberts M, Cirovic C, Gilchrist A (2003) Targeted disruption of the PDZK1 gene by homologous recombination. Mol Cell Biol 23:1175-1180

88. Kojima H, Nies AT, König J, Hagmann W, Spring H, Uemura M, Fukui H, Keppler D (2003) Changes in the expression and localization of hepatocellular transporters and radixin in primary biliary cirrhosis. J Hepatol 39:693-702

89. König J, Nies AT, Cui Y, Leier I, Keppler D (1999) Conjugate export pumps of the multidrug resistance protein (MRP) family: localization, substrate specificity, and MRP2-mediated drug resistance. Biochim Biophys Acta 1461:377-394

90. König J, Rost D, Cui Y, Keppler D (1999) Characterization of the human multidrug resistance protein isoform MRP3 localized to the basolateral hepatocyte membrane. Hepatology 29:1156-1163

91. König J, Nies AT, Cui Y, Keppler D (2003) MRP2, the apical export pump for anionic conjugates. In: Holland IB, Kuchler K, Higgins C, Cole SPC (eds) ABC proteins: from bacteria to man. Academic, London, pp 423-443

92. König J, Hartel M, Nies AT, Martignoni ME, Guo J, Büchler MW, Friess H, Keppler D (2005) Expression and localization of human multidrug resistance protein $(\mathrm{ABCC})$ family members in pancreatic carcinoma. Int J Cancer 115:359-367

93. Konno $T$, Ebihara $T$, Hisaeda $K$, Uchiumi $T$, Nakamura $T$, Shirakusa T, Kuwano M, Wada M (2003) Identification of domains participating in the substrate specificity and subcellular localization of the multidrug resistance proteins MRP1 and MRP2. J Biol Chem 278:22908-22917

94. Kool M, van der Linden M, de Haas M, Scheffer GL, de Vree JM, Smith AJ, Jansen G, Peters GJ, Ponne N, Scheper RJ, Elferink RP, Baas F, Borst P (1999) MRP3, an organic anion transporter able to transport anti-cancer drugs. Proc Natl Acad Sci USA 96:6914-6919

95. Kopplow K, Letschert K, König J, Walter B, Keppler D (2005) Human hepatobiliary transport of organic anions analyzed by quadruple-transfected cells. Mol Pharmacol 68:1031-1038

96. Kruh GD, Belinsky MG (2003) The MRP family of drug efflux pumps. Oncogene 22:7537-7552

97. Kubitz R, D’Urso D, Keppler D, Häussinger D (1997) Osmodependent dynamic localization of the multidrug resistance protein 2 in the rat hepatocyte canalicular membrane. Gastroenterology 113:1438-1442

98. Kubitz R, Warskulat U, Schmitt M, Häussinger D (1999) Dexamethasone- and osmolarity-dependent expression of the multidrug-resistance protein 2 in cultured rat hepatocytes. Biochem J 340:585-591

99. Kubitz R, Wettstein M, Warskulat U, Häussinger D (1999) Regulation of the multidrug resistance protein 2 in the rat liver by lipopolysaccharide and dexamethasone. Gastroenterology 116:401-410

100. Kubitz R, Huth C, Schmitt M, Horbach A, Kullak-Ublick G, Häussinger D (2001) Protein kinase C-dependent distribution of the multidrug resistance protein 2 from the canalicular to the basolateral membrane in human HepG2 cells. Hepatology 34:340-350

101. Kullak-Ublick GA, Baretton GB, Oswald M, Renner EL, Paumgartner G, Beuers U (2002) Expression of the hepatocyte canalicular multidrug resistance protein (MRP2) in primary biliary cirrhosis. Hepatol Res 23:78-82

102. Kullak-Ublick GA, Stieger B, Meier PJ (2004) Enterohepatic bile salt transporters in normal physiology and liver disease. Gastroenterology 126:322-342

103. Lee J, Azzaroli F, Wang L, Soroka CJ, Gigliozzi A, Setchell KD, Kramer W, Boyer JL (2001) Adaptive regulation of bile salt transporters in kidney and liver in obstructive cholestasis in the rat. Gastroenterology 121:1473-1484
104. Lee JH, Chen HL, Chen HL, Ni YH, Hsu HY, Chang MH (2006) Neonatal Dubin-Johnson syndrome: long-term follow-up and MRP2 mutations study. Pediatr Res 59:584-589

105. Leier I, Jedlitschky G, Buchholz U, Cole SPC, Deeley RG, Keppler D (1994) The MRP gene encodes an ATP-dependent export pump for leukotriene $\mathrm{C} 4$ and structurally related conjugates. J Biol Chem 269:27807-27810

106. Leier I, Jedlitschky G, Buchholz U, Keppler D (1994) Characterization of the ATP-dependent leukotriene C4 export carrier in mastocytoma cells. Eur J Biochem 220:599-606

107. Leier I, Hummel-Eisenbeiss J, Cui Y, Keppler D (2000) ATPdependent para-aminohippurate transport by apical multidrug resistance protein MRP2. Kidney Int 57:1636-1642

108. Letschert K, Keppler D, König J (2004) Mutations in the SLCO1B3 gene affecting the substrate specificity of the hepatocellular uptake transporter OATP1B3 (OATP8). Pharmacogenetics 14:441-452

109. Letschert K, Komatsu M, Hummel-Eisenbeiss J, Keppler D (2005) Vectorial transport of the peptide CCK-8 by doubletransfected MDCKII cells stably expressing the organic anion transporter OATP1B3 (OATP8) and the export pump ABCC2. J Pharmacol Exp Ther 313:549-556

110. Loe DW, Almquist KC, Deeley RG, Cole SP (1996) Multidrug resistance protein (MRP)-mediated transport of leukotriene $\mathrm{C} 4$ and chemotherapeutic agents in membrane vesicles. Demonstration of glutathione-dependent vincristine transport. J Biol Chem 271:9675-9682

111. Machida I, Inagaki Y, Suzuki S, Hayashi H, Wakusawa S (2004) Mutation analysis of the multidrug resistance protein 2 (MRP2) gene in a Japanese patient with Dubin-Johnson syndrome. Hepatol Res 30:86-90

112. Machida I, Wakusawa S, Sanae F, Hayashi H, Kusakabe A, Ninomiya H, Yano M, Yoshioka K (2005) Mutational analysis of the MRP2 gene and long-term follow-up of Dubin-Johnson syndrome in Japan. J Gastroenterol 40:366-370

113. Masuda M, I'izuka Y, Yamazaki M, Nishigaki R, Kato Y, Ni'inuma K, Suzuki H, Sugiyama Y (1997) Methotrexate is excreted into the bile by canalicular multispecific organic anion transporter in rats. Cancer Res 57:3506-3510

114. Mayer R, Kartenbeck J, Büchler M, Jedlitschky G, Leier I, Keppler D (1995) Expression of the MRP gene-encoded conjugate export pump in liver and its selective absence from the canalicular membrane in transport-deficient mutant hepatocytes. J Cell Biol 131:137-150

115. Miller DS, Nobmann SN, Gutmann H, Toeroek M, Drewe J, Fricker G (2000) Xenobiotic transport across isolated brain microvessels studied by confocal microscopy. Mol Pharmacol 58:1357-1367

116. Misra S, Ujhazy P, Gatmaitan Z, Varticovski L, Arias IM (1998) The role of phosphoinositide 3-kinase in taurocholate-induced trafficking of ATP-dependent canalicular transporters in rat liver. J Biol Chem 273:26638-26644

117. Mor-Cohen R, Zivelin A, Rosenberg N, Shani M, Muallem S, Seligsohn U (2001) Identification and functional analysis of two novel mutations in the multidrug resistance protein 2 gene in Israeli patients with Dubin-Johnson syndrome. J Biol Chem 276:36923-36930

118. Mor-Cohen R, Zivelin A, Rosenberg N, Goldberg I, Seligsohn U (2005) A novel ancestral splicing mutation in the multidrug resistance protein 2 gene causes Dubin-Johnson syndrome in Ashkenazi Jewish patients. Hepatol Res 31:104-111

119. Mottino AD, Cao J, Veggi LM, Crocenzi F, Roma MG, Vore M (2002) Altered localization and activity of canalicular Mrp2 in estradiol-17beta-D-glucuronide-induced cholestasis. Hepatology 35:1409-1419

120. Müller M, Meijer C, Zaman GJR, Borst P, Scheper RJ, Mulder NH, de Vries EGE, Jansen PLM (1994) Overexpression of the 
multidrug resistance associated protein (MRP) gene results in increased ATP-dependent glutathione S-conjugate transport. Proc Natl Acad Sci USA 91:13033-13037

121. Nezasa K, Tian X, Zamek-Gliszczynski MJ, Patel NJ, Raub TJ, Brouwer KL (2006) Altered hepatobiliary disposition of 5 (and 6)-carboxy-2',7'-dichlorofluorescein in Abcg2 (Bcrp1) and Abcc2 (Mrp2) knockout mice. Drug Metab Dispos 34:718-723

122. Nies AT, Cantz T, Brom M, Leier I, Keppler D (1998) Expression of the apical conjugate export pump, Mrp2, in the polarized hepatoma cell line, WIF-B. Hepatology 28:1332-1340

123. Nies AT, König J, Pfannschmidt M, Klar E, Hofmann WJ, Keppler D (2001) Expression of the multidrug resistance proteins MRP2 and MRP3 in human hepatocellular carcinoma. Int J Cancer 94:492-499

124. Nies AT, König J, Cui Y, Brom M, Spring H, Keppler D (2002) Structural requirements for the apical sorting of human multidrug resistance protein 2 (ABCC2). Eur J Biochem 269:1866-1876

125. Nies AT, Jedlitschky G, König J, Herold-Mende C, Steiner HH, Schmitt HP, Keppler D (2004) Expression and immunolocalization of the multidrug resistance proteins, MRP1-MRP6 (ABCC1-ABCC6), in human brain. Neuroscience 129:349-360

126. Niinuma K, Takenaka O, Horie T, Kobayashi K, Kato Y, Suzuki H, Sugiyama Y (1997) Kinetic analysis of the primary active transport of conjugated metabolites across the bile canalicular membrane: comparative study of S-(2,4-dinitrophenyl)-glutathione and 6-hydroxy-5,7-dimethyl-2-methylamino-4-(3-pyridylmethyl)benzothiazole glucuronide. J Pharmacol Exp Ther 282:866-872

127. Nishida T, Gatmaitan Z, Roy Chowdhury J, Arias IM (1992) Two distinct mechanisms for bilirubin glucuronide transport by rat bile canalicular membrane vesicles. Demonstration of defective ATP-dependent transport in rats (TR-) with inherited conjugated hyperbilirubinemia. J Clin Invest 90:2130-2135

128. Nishida T, Hardenbrook C, Gatmaitan Z, Arias IM (1992) ATPdependent organic anion transport system in normal and TR- rat liver canalicular membranes. Am J Physiol 262:G629-G635

129. Nuclear Receptors Nomenclature Committee (1999) A unified nomenclature system for the nuclear receptor superfamily. Cell 97:161-163

130. Oswald M, Kullak-Ublick GA, Paumgartner G, Beuers U (2001) Expression of hepatic transporters OATP-C and MRP2 in primary sclerosing cholangitis. Liver 21:247-253

131. Oude Elferink RPJ, Meijer DKF, Kuipers F, Jansen PLM, Groen AK, Groothuis GMM (1995) Hepatobiliary secretion of organic compounds: molecular mechanisms of membrane transport. Biochim Biophys Acta 1241:215-268

132. Parks DJ, Blanchard SG, Bledsoe RK, Chandra G, Consler TG, Kliewer SA, Stimmel JB, Willson TM, Zavacki AM, Moore DD, Lehmann JM (1999) Bile acids: natural ligands for an orphan nuclear receptor. Science 284:1365-1368

133. Paulusma CC, Bosma PJ, Zaman GJR, Bakker CTM, Otter M, Scheffer GL, Scheper RJ, Borst P, Oude Elferink RPJ (1996) Congenital jaundice in rats with a mutation in a multidrug resistance associated-protein gene. Science 271:1126-1128

134. Paulusma CC, Kool M, Bosma PJ, Scheffer GL, ter Borg F, Scheper RJ, Tytgat GNJ, Borst P, Baas F, Oude Elferink RPJ (1997) A mutation in the human canalicular multispecific organic anion transporter gene causes the Dubin-Johnson syndrome. Hepatology 25:1539-1542

135. Paulusma CC, van Meer MA, Evers R, Heijn M, Ottenhoff R, Borst P, Oude Elferink RP (1999) Canalicular multispecific organic anion transporter/multidrug resistance protein 2 mediates low-affinity transport of reduced glutathione. Biochem J 338:393-401

136. Paulusma CC, Kothe MJ, Bakker CT, Bosma PJ, van Bokhoven I, van Marle J, Bolder U, Tytgat GN, Oude Elferink RP (2000)
Zonal down-regulation and redistribution of the multidrug resistance protein 2 during bile duct ligation in rat liver. Hepatology 31:684-693

137. Payen L, Courtois A, Loewert M, Guillouzo A, Fardel O (2001) Reactive oxygen species-related induction of multidrug resistance-associated protein 2 expression in primary hepatocytes exposed to sulforaphane. Biochem Biophys Res Commun 282:257-263

138. Ramensky V, Bork P, Sunyaev S (2002) Human nonsynonymous SNPs: server and survey. Nucleic Acids Res 30:3894-3900

139. Rea PA, Li ZS, Lu YP, Drozdowicz YM, Martinoia E (1998) From vacuolar GS-X pumps to multispecific $\mathrm{ABC}$ transporters. Annu Rev Plant Physiol Plant Mol Biol 49:727-760

140. Rius M, Nies AT, Hummel-Eisenbeiss J, Jedlitschky G, Keppler D (2003) Cotransport of reduced glutathione with bile salts by MRP4 (ABCC4) localized to the basolateral hepatocyte membrane. Hepatology 38:374-384

141. Rius M, Hummel-Eisenbeiss J, Hofmann AF, Keppler D (2006) Substrate specificity of human ABCC4 (MRP4)-mediated cotransport of bile acids and reduced glutathione. Am J Physiol Gasterointest Liver Physiol 290:G640-G649

142. Roelofsen H, Soroka CJ, Keppler D, Boyer JL (1998) Cyclic AMP stimulates sorting of the canalicular organic anion transporter (Mrp2/cMoat) to the apical domain in hepatocyte couplets. J Cell Sci 111:1137-1145

143. Rost D, Kartenbeck J, Keppler D (1999) Changes in the localization of the rat canalicular conjugate export pump Mrp2 in phalloidin-induced cholestasis. Hepatology 29:814-821

144. Rost D, König J, Weiss G, Klar E, Stremmel W, Keppler D (2001) Expression and localization of the multidrug resistance proteins MRP2 and MRP3 in human gallbladder epithelia. Gastroenterology 121:1203-1208

145. Roy Chowdhury N, Arias IM, Wolkoff AW, Roy Chowdhury J (2001) Disorders of bilirubin metabolism. In: Arias IM, Boyer JL, Chisari FV, Fausto N, Schachter D, Shafritz DA (eds) The liver: biology and pathobiology. Lippincott, Williams \& Wilkins, Philadelphia, pp 291-309

146. Saito S, Iida A, Sekine A, Miura Y, Ogawa C, Kawauchi S, Higuchi S, Nakamura Y (2002) Identification of 779 genetic variations in eight genes encoding members of the ATPbinding cassette, subfamily $\mathrm{C}$ (ABCC/MRP/CFTR). J Hum Genet 47:147-171

147. Sandusky GE, Mintze KS, Pratt SE, Dantzig AH (2002) Expression of multidrug resistance-associated protein 2 (MRP2) in normal human tissues and carcinomas using tissue microarrays. Histopathology 41:65-74

148. Sasabe H, Tsuji A, Sugiyama Y (1998) Carrier-mediated mechanism for the biliary excretion of the quinolone antibiotic grepafloxacin and its glucuronide in rats. J Pharmacol Exp Ther 284:1033-1039

149. Sasaki M, Suzuki H, Ito K, Abe T, Sugiyama Y (2002) Transcellular transport of organic anions across a double-transfected Madin-Darby canine kidney II cell monolayer expressing both human organic anion-transporting polypeptide (OATP2/ SLC21A6) and multidrug resistance-associated protein 2 (MRP2/ABCC2). J Biol Chem 277:6497-6503

150. Schaub TP, Kartenbeck J, König J, Vogel O, Witzgall R, Kriz W, Keppler D (1997) Expression of the conjugate export pump encoded by the mrp2 gene in the apical membrane of kidney proximal tubules. J Am Soc Nephrol 8:1213-1221

151. Schaub TP, Kartenbeck J, König J, Spring H, Dörsam H, Stähler G, Störkel S, Thon WF, Keppler D (1999) Expression of the MRP2 gene-encoded conjugate export pump in human kidney proximal tubules and in renal-cell carcinoma. J Am Soc Nephrol 10:1159-1169 
152. Shani M, Seligsohn U, Gilon E, Sheba C, Adam A (1970) Dubin-Johnson syndrome in Israel. I. Clinical, laboratory, and genetic aspects of 101 cases. Q J Med 39:549-567

153. Shoda J, Kano M, Oda K, Kamiya J, Nimura Y, Suzuki H, Sugiyama Y, Miyazaki H, Todoroki T, Stengelin S, Kramer W, Matsuzaki Y, Tanaka N (2001) The expression levels of plasma membrane transporters in the cholestatic liver of patients undergoing biliary drainage and their association with the impairment of biliary secretory function. Am J Gastroenterol 96:3368-3378

154. Shoda J, Suzuki H, Suzuki H, Sugiyama Y, Hirouchi M, Utsunomiya H, Oda K, Kawamoto T, Matsuzaki Y, Tanaka N (2003) Novel mutations identified in the human multidrug resistance-associated protein 2 (MRP2/ABCC2) gene in a Japanese patient with Dubin-Johnson syndrome. Hepatol Res 27:323-326

155. Smeets PH, van Aubel RA, Wouterse AC, van den Heuvel JJ, Russel FG (2004) Contribution of multidrug resistance protein 2 (MRP2/ABCC2) to the renal excretion of p-aminohippurate (PAH) and identification of MRP4 (ABCC4) as a novel PAH transporter. J Am Soc Nephrol 15:2828-2835

156. Smitherman PK, Townsend AJ, Kute TE, Morrow CS (2004) Role of multidrug resistance protein 2 (MRP2, ABCC2) in alkylating agent detoxification: MRP2 potentiates glutathione Stransferase A1-1-mediated resistance to chlorambucil cytotoxicity. J Pharmacol Exp Ther 308:260-267

157. Spears KJ, Ross J, Stenhouse A, Ward CJ, Goh LB, Wolf CR, Morgan P, Ayrton A, Friedberg TH (2005) Directional transepithelial transport of organic anions in porcine LLC-PK1 cells that co-express human OATP1B1 (OATP-C) and MRP2. Biochem Pharmacol 69:415-423

158. Sprinz H, Nelson RS (1954) Persistent nonhemolytic hyperbilirubinemia associated with lipochrome-like pigment in liver cells; report of four cases. Ann Intern Med 41:952-962

159. St-Pierre MV, Serrano MA, Macias RI, Dubs U, Hoechli M, Lauper U, Meier PJ, Marin JJ (2000) Expression of members of the multidrug resistance protein family in human term placenta. Am J Physiol Regul Integr Comp Physiol 279:R1495-R1503

160. Stöckel B, König J, Nies AT, Cui Y, Brom M, Keppler D (2000) Characterization of the 5'-flanking region of the human multidrug resistance protein 2 (MRP2) gene and its regulation in comparison with the multidrug resistance protein 3 (MRP3). Eur J Biochem 267:1347-1358

161. Sueyoshi T, Kawamoto T, Zelko I, Honkakoski P, Negishi M (1999) The repressed nuclear receptor CAR responds to phenobarbital in activating the human CYP2B6 gene. J Biol Chem 274:6043-6046

162. Suzuki H, Sugiyama Y (2002) Single nucleotide polymorphisms in multidrug resistance associated protein 2 (MRP2/ ABCC2): its impact on drug disposition. Adv Drug Deliv Rev 54:1311-1331

163. Takikawa H, Sano N, Narita T, Uchida Y, Yamanaka M, Horie T, Mikami T, Tagaya O (1991) Biliary excretion of bile acid conjugates in a hyperbilirubinemic mutant Sprague-Dawley rat. Hepatology 14:352-360

164. Tanaka T, Uchiumi T, Hinoshita E, Inokuchi A, Toh S, Wada M, Takano H, Kohno K, Kuwano M (1999) The human multidrug resistance protein 2 gene: functional characterization of the $5^{\prime}$-flanking region and expression in hepatic cells. Hepatology 30:1507-1512

165. Taniguchi K, Wada M, Kohno K, Nakamura T, Kawabe T, Kawakami M, Kagotani K, Okumura K, Akiyama S, Kuwano M (1996) A human canalicular multispecific organic anion transporter (cMOAT) overexpressed in cisplatin-resistant human cancer cell lines with decreased drug accumulation. Cancer Res $56: 4124-4129$

166. Tate G, Li M, Suzuki T, Mitsuya T (2002) A new mutation of the ATP-binding cassette, sub-family $\mathrm{C}$, member 2 (ABCC2) gene in a Japanese patient with Dubin-Johnson syndrome. Genes Genet Syst 77:117-121

167. Thermann R, Neu-Yilik G, Deters A, Frede U, Wehr K, Hagemeier C, Hentze MW, Kulozik AE (1998) Binary specifications of nonsense codons by splicing and cytoplasmic translation. EMBO J 17:3484-3494

168. Toh S, Wada M, Uchiumi T, Inokuchi A, Makino Y, Horie Y, Adachi Y, Sakisaka S, Kuwano M (1999) Genomic structure of the canalicular multispecific organic anion-transporter gene (MRP2/ cMOAT) and mutations in the ATP-binding-cassette region in Dubin-Johnson syndrome. Am J Hum Genet 64:739-746

169. Trauner M, Arrese M, Soroka CJ, Ananthanarayanan M, Koeppel TA, Schlosser SF, Suchy FJ, Keppler D, Boyer JL (1997) The rat canalicular conjugate export pump (Mrp2) is down-regulated in intrahepatic and obstructive cholestasis. Gastroenterology 113:255-264

170. Tsujii H, König J, Rost D, Stöckel B, Leuschner U, Keppler D (1999) Exon-intron organization of the human multidrugresistance protein 2 (MRP2) gene mutated in Dubin-Johnson syndrome. Gastroenterology 117:653-660

171. van Aubel RA, van Kuijck MA, Koenderink JB, Deen PM, van Os CH, Russel RG (1998) Adenosine triphosphate-dependent transport of anionic conjugates by the rabbit multidrug resistance-associated protein Mrp2 expressed in insect cells. Mol Pharmacol 53:1062-1067

172. van Aubel RA, Hartog A, Bindels RJ, van Os CH, Russel FG (2000) Expression and immunolocalization of multidrug resistance protein 2 in rabbit small intestine. Eur J Pharmacol 400:195-198

173. van Aubel RA, Peters JG, Masereeuw R, van Os CH, Russel FG (2000) Multidrug resistance protein mrp2 mediates ATP-dependent transport of classic renal organic anion p-aminohippurate. Am J Physiol Renal Physiol 279:F713-F717

174. van Aubel RA, Smeets PH, Peters JG, Bindels RJ, Russel FG (2002) The MRP4/ABCC4 gene encodes a novel apical organic anion transporter in human kidney proximal tubules: putative efflux pump for urinary cAMP and cGMP. J Am Soc Nephrol 13:595-603

175. van de Water FM, Masereeuw R, Russel FG (2005) Function and regulation of multidrug resistance proteins (MRPs) in the renal elimination of organic anions. Drug Metab Rev 37:443-471

176. van Vliet EA, Redeker S, Aronica E, Edelbroek PM, Gorter JA (2005) Expression of multidrug transporters MRP1, MRP2, and BCRP shortly after status epilepticus, during the latent period, and in chronic epileptic rats. Epilepsia 46:1569-1580

177. Vlaming ML, Mohrmann K, Wagenaar E, de Waart DR, Oude Elferink RP, Lagas JS, van Tellingen O, Vainchtein LD, Rosing H, Beijnen JH, Schellens JH, Schinkel AH (2006) Carcinogen and anti-cancer drug transport by Mrp2 in vivo: studies using Mrp2 (Abcc2) knockout mice. J Pharmacol Exp Ther DOI: 10.1124/jpet.106.101774

178. Vos TA, Hooiveld GJ, Koning H, Childs S, Meijer DK, Moshage H, Jansen PL, Müller M (1998) Up-regulation of the multidrug resistance genes, Mrp1 and Mdr1b, and down-regulation of the organic anion transporter, Mrp2, and the bile salt transporter, Spgp, in endotoxemic rat liver. Hepatology 28:1637-1644

179. Wada M (2006) Single nucleotide polymorphisms in ABCC2 and $\mathrm{ABCB} 1$ genes and their clinical impact in physiology and drug response. Cancer Lett 234:40-50

180. Wada M, Toh S, Taniguchi K, Nakamura T, Uchiumi T, Kohno K, Yoshida I, Kimura A, Sakisaka S, Adachi Y, Kuwano M (1998) Mutations in the canalicular multispecific organic anion transporter (cMOAT) gene, a novel $\mathrm{ABC}$ transporter, in patients with hyperbilirubinemia II/Dubin-Johnson syndrome. Hum Mol Genet 7:203-207

181. Wakusawa S, Machida I, Suzuki S, Hayashi H, Yano M, Yoshioka K (2003) Identification of a novel 2026G->C mutation 
of the MRP2 gene in a Japanese patient with Dubin-Johnson syndrome. J Hum Genet 48:425-429

182. Walgren RA, Karnaky KJ Jr, Lindenmayer GE, Walle T (2000) Efflux of dietary flavonoid quercetin 4'-beta-glucoside across human intestinal Caco-2 cell monolayers by apical multidrug resistance-associated protein-2. J Pharmacol Exp Ther 294:830-836

183. Westlake CJ, Cole SP, Deeley RG (2005) Role of the NH2 terminal membrane spanning domain of multidrug resistance protein $1 / \mathrm{ABCC} 1$ in protein processing and trafficking. Mol Biol Cell 16:2483-2492

184. Wielandt AM, Vollrath V, Manzano M, Miranda S, Accatino L, Chianale J (1999) Induction of the multispecific organic anion transporter (cMoat/mrp2) gene and biliary glutathione secretion by the herbicide 2,4,5-trichlorophenoxyacetic acid in the mouse liver. Biochem J 341:105-111

185. Xiong H, Suzuki H, Sugiyama Y, Meier PJ, Pollack GM, Brouwer KL (2002) Mechanisms of impaired biliary excretion of acetaminophen glucuronide after acute phenobarbital treatment or phenobarbital pretreatment. Drug Metab Dispos 30:962-969

186. Yamada T, Arai T, Nagino M, Oda K, Shoda J, Suzuki H, Sugiyama Y, Nimura Y (2005) Impaired expression of hepatic multidrug resistance protein 2 is associated with posthepatectomy hyperbilirubinemia in patients with biliary cancer. Langenbecks Arch Surg 390:421-429

187. Yamazaki M, Akiyama S, Ni'inuma K, Nishigaki R, Sugiyama Y (1997) Biliary excretion of pravastatin in rats: contribution of the excretion pathway mediated by canalicular multispecific organic anion transporter. Drug Metab Dispos 25:1123-1129

188. Zhang Y, Schuetz JD, Elmquist WF, Miller DW (2004) Plasma membrane localization of multidrug resistance-associated protein homologs in brain capillary endothelial cells. J Pharmacol Exp Ther 311:449-455

189. Zollner G, Fickert P, Zenz R, Fuchsbichler A, Stumptner C, Kenner L, Ferenci P, Stauber RE, Krejs GJ, Denk H, Zatloukal K, Trauner M (2001) Hepatobiliary transporter expression in percutaneous liver biopsies of patients with cholestatic liver diseases. Hepatology 33:633-646

190. Zollner G, Wagner M, Fickert P, Silbert D, Fuchsbichler A, Zatloukal K, Denk H, Trauner M (2005) Hepatobiliary transporter expression in human hepatocellular carcinoma. Liver Int 25:367-379 